OPEN ACCESS

Edited by: Jin S. Im,

University of Texas MD Anderson Cancer Center,

United States

Reviewed by:

Giulia Casorati,

San Raffaele Hospital (IRCCS), Italy

Luc Van Kaer.

Vanderbilt University,

United States

*Correspondence:

Peter J. K. Kuppen

p.j.k.kuppen@/umc.nl

Specialty section:

This article was submitted

to Cancer Immunity

and Immunotherapy,

a section of the journal

Frontiers in Immunology

Received: 08 November 2017 Accepted: 09 February 2018

Published: 27 February 2018

Citation:

Krijgsman D, Hokland $M$ and Kuppen PJK (2018) The Role of Natural Killer T Cells in Cancer-A Phenotypical and Functional Approach.

Front. Immunol. 9:367. doi: 10.3389/fimmu.2018.00367

\section{The Role of Natural Killer T Cells in Cancer-A Phenotypical and Functional Approach}

\author{
Daniëlle Krijgsman ${ }^{1,2}$, Marianne Hokland ${ }^{2}$ and Peter J. K. Kuppen ${ }^{1 *}$ \\ ${ }^{1}$ Department of Surgery, Leiden University Medical Center, Leiden, Netherlands, ${ }^{2}$ Department of Biomedicine, \\ Aarhus University, Aarhus, Denmark
}

Natural killer T (NKT) cells are a subset of CD1d-restricted T cells at the interface between the innate and adaptive immune system. NKT cells can be subdivided into functional subsets that respond rapidly to a wide variety of glycolipids and stress-related proteins using T- or natural killer (NK) cell-like effector mechanisms. Because of their major modulating effects on immune responses via secretion of cytokines, NKT cells are also considered important players in tumor immunosurveillance. During early tumor development, $T$ helper $\left(T_{H}\right) 1$-like NKT cell subsets have the potential to rapidly stimulate tumor-specific T cells and effector NK cells that can eliminate tumor cells. In case of tumor progression, NKT cells may become overstimulated and anergic leading to deletion of a part of the NKT cell population in patients via activation-induced cell death. In addition, the remaining NKT cells become hyporesponsive, or switch to immunosuppressive $T_{H} 2-/ T$ regulatory-like NKT cell subsets, thereby facilitating tumor progression and immune escape. In this review, we discuss this important role of NKT cells in tumor development and we conclude that there should be three important focuses of future research in cancer patients in relation with NKT cells: (1) expansion of the NKT cell population, (2) prevention and breaking of NKT cell anergy, and (3) skewing of NKT cells toward $T_{H} 1$-like subsets with antitumor activity.

\section{Keywords: natural killer T cells, cancer, tumor immunology, immune escape, immunotherapy}

\section{KEY POINTS}

- NKT cells comprise a unique subset of CD1d-restricted T cells with characteristics of both NKand $\mathrm{T}$ cells that can be subdivided into functional subsets.

- NKT cells are able to switch between different functional subsets upon cell-cell interaction or interaction with signaling molecules.

- Activated NKT cells have a major regulatory effect on other immune cells via cytokine production and cell-cell interaction, which results in amplification or dampening of the immune response.

- $\mathrm{T}_{\mathrm{H}} 1$-like NKT cells have the potential to induce an antitumor response while $\mathrm{T}_{\mathrm{H}} 2$ - and $\mathrm{T}_{\mathrm{reg}}$-like NKT cell subsets facilitate immune escape and tumor progression.

- Overstimulation of NKT cells during tumor progression might lead to induction of anergy and skewing of NKT cells toward $\mathrm{T}_{\mathrm{H}} 2-/ \mathrm{T}_{\mathrm{reg}}$-like subsets, thereby facilitating tumor progression and immune escape.

- In cancer patients, there should be three important focuses of future research: (1) expansion of the NKT cell population, (2) prevention and breaking of NKT cell anergy, and (3) skewing of NKT cells toward $\mathrm{T}_{\mathrm{H}} 1$-like subsets with antitumor activity. 


\section{INTRODUCTION}

The immune system is a host defense mechanism that plays a pivotal role in the protection against pathogens and cancer (1). It comprises multiple specialized subsets of cells that differentiate from a common pluripotent progenitor, the hematopoietic stem cell (2). These subsets include natural killer T (NKT) cells that feature characteristics of both conventional $\mathrm{T}$ cells and natural killer (NK) cells. Upon activation, NKT cells are able to kill target cells either directly (3-5) or indirectly by influencing both myeloid- and lymphoid-derived immune cells (6). Moreover, NKT cells are potent immune regulators since they can skew immune responses toward both inflammation and tolerance very quickly by secreting either $T$ helper $\left(\mathrm{T}_{\mathrm{H}}\right) 1-, \mathrm{T}_{\mathrm{H}} 2-, \mathrm{T}_{\mathrm{H}} 17-$, $\mathrm{T}$ regulatory $\left(\mathrm{T}_{\text {reg }}\right)$-, or follicular helper $\left(\mathrm{T}_{\mathrm{FH}}\right)$-cell-associated cytokines (7). Because of their major modulating effects on immune responses, NKT cells have also been considered important mediators of tumor immunosurveillance (8). The role of NKT cells in relation to cancer has therefore been the focus of recent studies. In this review, we discuss the role of NKT cells in cancer in relation to their phenotype and function. We focus on non-hematological malignancies, i.e., carcinomas, sarcomas, melanomas, and neuroblastomas. First, the development and function of NKT cells are addressed in healthy individuals. Thereafter, the role of NKT cells is discussed in the development and progression of cancer. Finally, available NKT cell-based immunotherapies are presented and possibilities for future research are discussed.

\section{DEVELOPMENT AND LOCALIZATION OF NKT CELLS}

NKT cells constitute a unique, but highly heterogeneous, subset of immune cells that arise in the thymus from $\mathrm{CD}^{+}{ }^{+} \mathrm{CD}^{+}$cortical thymocytes that have undergone T cell receptor (TCR) gene rearrangement, as is the case with conventional T cells (9). TCRs are composed of an $\alpha$ - and a $\beta$-chain, each containing a variable and constant domain. The TCR $\alpha$-chain is generated by recombination of the variable $(\mathrm{V})$ and joining $(\mathrm{J})$ segments, whereas the $\beta$-chain also requires diversity (D)-segment recombination. Based on their TCR repertoire, two NKT cell subsets have been described: type I and type II NKT cells. Type I NKT cells were first identified in mice in 1990 as a unique T cell population expressing the Vo14Jo18 invariant TCR $\alpha$-chain. The type I NKT cell subset recognizes the glycosphingolipid $\alpha$-galactosylceramide $(\alpha$-GalCer) or its synthetic analogs when presented by major histocompatibility complex (MHC) class I-like CD1d molecules (10-12). Four years after the identification of the invariant V $\alpha 14 \mathrm{~J} \alpha 18$ TCR $\alpha$-chain in mice, the human counterpart V $\alpha 24 \mathrm{~J} \alpha 18$ was discovered which predominantly pairs with the V $\beta 11$ TCR $\beta$-chain (13-16). In addition to type I NKT cells, type II NKT cells are described with a more diverse and less well-defined TCR repertoire recognizing non- $\alpha$-GalCer molecules (primarily sulfatide) presented by CD1d molecules (12, 17-19).

\section{Development of Type I NKT Cells in Mice}

The development of type I NKT cells has been thoroughly studied in mice. During positive selection in the murine thymus, $\mathrm{T}$ cells expressing TCRs that are capable of binding to MHC class I or II molecules on cortical thymic epithelial cells are selected to undergo lineage commitment (9). This process leads to maturation of $\mathrm{CD}^{+}$or $\mathrm{CD}^{+} \mathrm{T}$ cells that recognize MHC-presented peptides. Alternatively, type I NKT cells that express the randomly rearranged invariant $\mathrm{V} \alpha 14 \mathrm{~J} \alpha 18$ chain are positively selected upon binding to CD1d molecules expressed by cortical thymocytes $(9,20-22)$. As a result of this alternative positive selection, they recognize lipid-derived antigens presented by CD1d molecules (10). During the maturation process, a part of the type I NKT cell population retains expression of the T cellassociated marker $\mathrm{CD} 4$, resulting in two major populations in mice: $\mathrm{CD}^{+} \mathrm{CD}^{-}$and $\mathrm{CD} 4^{-} \mathrm{CD} 8^{-}$(double negative, $\mathrm{DN}$ ) type I NKT cells $(23,24)$. In addition, Type I NKT cells acquire expression of the natural killer receptor (NKR) NK1.1 during maturation (9).

\section{Development of Type I NKT Cells in Humans}

Although the thymic development of type I NKT cells is well defined in mice, it has not as yet been studied in details in humans. It has been reported that NKT precursor cells can be identified in thymic tissue derived from human embryos and young children $(25,26)$. Similar to type I NKT cell development in mice, human type I NKT cells express cell surface markers that are usually associated with both T- and NK cells. For instance, a part of the human type I NKT cell population retains expression of the $\mathrm{T}$ cell-associated markers $\mathrm{CD} 4$ or CD8 during maturation, resulting in three major populations in humans: $\mathrm{CD}^{+}{ }^{+} \mathrm{CD} 8^{-}, \mathrm{CD}^{-}{ }^{-} \mathrm{CD} 8^{+}$, and $\mathrm{DN}$ type I NKT cells $(27,28)$. In addition, a part of the human type I NKT cells acquires expression of the NK cell-associated marker CD161 (the human counterpart of NK1.1 in mice), the classical NK cell marker in humans CD56 (27-29), and various other NK cellassociated receptors (27-31).

\section{Localization of Type I NKT Cells in Humans}

After development and maturation in the thymus, NKT cells migrate to the periphery. In general, human type I NKT cells are present in small numbers $(<0.1 \%$ of total T lymphocytes) in peripheral blood (PB), lymph nodes, spleen, thymus, lung, and bone marrow (32-34), whereas larger type I NKT cell populations reside in the liver, colon, kidney $(\sim 1 \%$ of total T lymphocytes) (35-37), and omentum ( 10\% of total T lymphocytes) (38). Importantly, it has to be taken into account that NKT cell numbers vary substantially among healthy individuals. For instance, circulating type I NKT cells have been reported to comprise more than $5 \%$ of the total T lymphocyte population in some individuals (39).

\section{Morphology of NKT Cells}

Despite the fact that NKT cells are derived from the T cell lineage, their morphology resembles NK cells more closely. NK and NKT cells are both referred to as large granular lymphocytes, whereas T cells are described as small and non-granular (40-42). 
In addition, NKT cells were reported to have a low nuclear-tocytoplasmic ratio and their nucleus contained dispersed chromatin, similar to NK cells (41, 43-45).

\section{CHARACTERIZATION AND IDENTIFICATION OF HUMAN NKT CELL SUBSETS}

In addition to classification of NKT cells in type I and type II NKT cells based on their TCR repertoire, human NKT cells can also be classified into functional subsets based on their cytokine secretion pattern upon activation, using a similar approach as for $\mathrm{T}_{\mathrm{H}}$-cell subsets (7).

\section{Functional Type I NKT Cell Subsets}

At the moment, type I NKT cells can be divided into five different functional subsets (Figure 1). $\mathrm{T}_{\mathrm{H}} 1$-like type I NKT cells have been identified in healthy individuals producing $\mathrm{T}_{\mathrm{H}} 1$-associated cytokines such as IFN- $\gamma$ and TNF- $\alpha$ upon stimulation $(7,30,46)$. The majority of these type I NKT cells are DN and are thought to exert limited cytotoxic function $(30,46)$. They are able to induce an effective pro-inflammatory immune cascade through cytokine signaling. Furthermore, a second $\mathrm{T}_{\mathrm{H}} 2$-like type I NKT cell subset with regulatory properties has been described secreting IL-4 and IL-13 upon activation $(7,30,46)$. This type I NKT cell subset mainly consists of $\mathrm{CD}^{+} \mathrm{CD}^{-}$cells which are able to suppress immune responses in various disease models (47-49). Recently, three additional minor type I NKT cell subsets were identified. $\mathrm{T}_{\mathrm{H}}$ 17-like type I NKT cells have been described, secreting the pro-inflammatory cytokines IL-17, IL-21, and IL-22 when activated $(50,51)$. In addition, FOXP3 expressing $\mathrm{T}_{\text {reg }}$-like type I NKT cells secreting the immunosuppressive cytokine IL-10 have been identified (52), as well as $\mathrm{T}_{\mathrm{FH}}$-like type I NKT cells secreting IL-21 upon activation $(46,53)$. Interestingly, murine studies showed that functional type I NKT cell subsets (Figure 1) express unique transcription factors and the "choice" to become a certain subset appears to be set in the thymus during fetal development (54). The fate of type I NKT cells might, however, not be permanently determined at this time since their cytokine production upon activation can be influenced by the microenvironment $(27,55)$, similar to $\mathrm{T}_{\mathrm{H}^{-}}$-cell subsets $(56)$. For instance, the cytokine secretion pattern of type I NKT cells is altered by the presence of immunosuppressive cytokines and/or immune cell subsets in the tumor microenvironment (TME) (57), as well as costimulation via CD28 (58), thereby implying plasticity of type I NKT cell subsets.

\section{Identification of Type I NKT Cell Subsets}

NKT cells can be identified from human peripheral blood mononuclear cells (PBMCs) with flow cytometry using monoclonal antibodies $(\mathrm{mAb})$ and multimers as thoroughly described by Metelitsa (59). For instance, type I NKT cells have often been identified by costaining with anti-V 224 (clone C15) and anti-V $\beta 11$ (clone C21) mAb $(27,29,60,61)$. However, this $\mathrm{mAb}$ combination leads to overestimation of type I NKT cell numbers since conventional $\mathrm{T}$ cells can also express $\mathrm{V} \alpha 24$ and V $\beta 11$ TCR subunits $(62,63)$. Alternatively, type I NKT cells can be detected with anti-V $\alpha 24 \mathrm{~J} \alpha 18$ (Clone 6B11) mAb $(28,31$ ). Furthermore, $\alpha$-GalCer-loaded CD1d dimers (64) and tetramers $(30,65-67)$ can be used to specifically detect CD1d-restricted type I NKT cells, for instance, in combination with anti-CD3, anti-V $\alpha 24$, or anti-V $\beta 11 \mathrm{mAb}$. Importantly, Sag et al. reported on the detection of cytokines in type I NKT cells upon stimulation, which enables accurate identification of different functional NKT cell subsets in future studies (68). Since this approach has not been used in NKT phenotype studies yet, no information is available on the phenotype of the different functional NKT cell subsets.

\section{Phenotype of Type I NKT Cell Subsets}

Type I NKT cells constitutively express various $\mathrm{T}$ cell markers such as the TCR signaling complex CD3, and costimulatory receptors such as CD4, CD8, and CD28 (27-31). CD4 is expressed

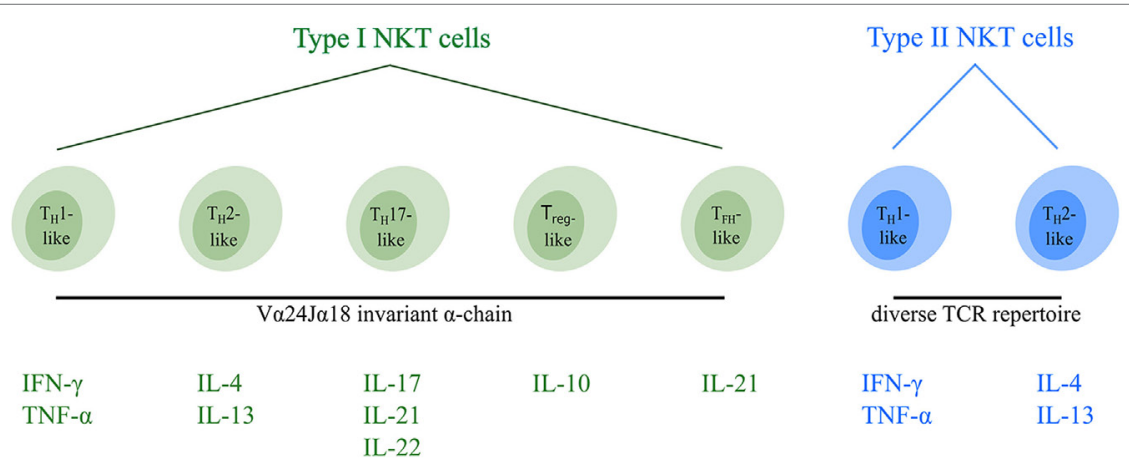

FIGURE 1 | Overview of the different functional human NKT cell subsets. CD1d-restricted human NKT cells can be divided into subsets based on their TCR repertoire and cytokine profile. Type I NKT cells express the invariant V $\alpha 24 \mathrm{~J} \alpha 18 \mathrm{TCR} \alpha$-chain and can be subdivided into five distinct functional subsets (indicated in green). In addition, type II NKT cells express a diverse TCR repertoire and can be subdivided into two functional subsets (indicated in blue). Upon activation, NKT cells secrete a unique pattern of cytokines, indicated for each subtype. Type I and type II NKT cells are able to switch between different functional subsets upon interactions within the TME. Abbreviations: NKT, natural killer T; TCR, T cell receptor; $T_{H}$, helper $T$; $T_{\text {reg, }}$, regulatory $T$; $T_{F H}$, follicular helper T; TME, tumor microenvironment. 
by $15-80 \%$ of the type I NKT cell population $(27-29,31)$ and is sometimes used to subdivide type I NKT cells into $\mathrm{CD}^{-}$and $\mathrm{CD}^{+}$populations. Besides, type I NKT cells constitutively express various receptors that are usually observed on NK cells, such as the adhesion molecule CD56 and the activating NKR CD161 (27-30). 17-70\% of the CD4- type I NKT cells express CD56, in contrast to only a small fraction of the CD4 $4^{+}$type I NKT cell population (3-11\%) (29). Interestingly, type I NKT cells acquire a memory-activated phenotype before birth (unlike NK- and T cells), reflected by high expression of CD45RO and low expression of the homing receptor CD62L $(28,29,31,69)$. This might indicate that these NKT cells have been sensitized and activated during fetal life by encountering a natural ligand (69), which contributes to the ability of NKT cells to respond fast upon meeting the antigen.

In addition, type I NKT cells have the ability to induce expression of a number of phenotypic markers upon activation and/or interactions within the microenvironment. For instance, type I NKT cells can upregulate CD62L expression upon $\alpha$-GalCer-mediated activation and expansion which can serve as a marker for NKT cells with superior survival and proliferative capacity (70). In addition, $\mathrm{CD}^{+}$and $\mathrm{DN}$ type I NKT cells express CD69, which is involved in lymphocyte proliferation $(28,71)$. Upon cytokine-mediated activation, type I NKT cells upregulate CD69 expression. Furthermore, CD4 ${ }^{+}$, $\mathrm{CD}^{+}$, and DN type I NKT cells express CD27, a costimulatory immune-checkpoint molecule involved in the control of $\mathrm{T}$ cell immunity $(28,29,31)$. Remarkably, expression of CD27 seems to be downregulated on type I NKT cells upon activation with $\alpha$-GalCer, whereas its expression is upregulated in activated $\mathrm{T}$ cells $(72,73)$. This downregulation could be related to the fact that NKT cells already constitute a memory phenotype and, therefore, do not require CD27 to generate NKT cell immunity and maturation upon first antigen encounter. $\alpha$-GalCer-activated type I NKT cells also express the costimulatory molecule CD40L, and the activation marker CD38 $(28,30$, $31,71)$. In addition, type I NKT cells express the inhibitory NKR NKG2A, the low affinity Fc receptor CD16, and the activating NKRs DNAM-1, NKG2D, NKp30, NKp44, NKp46, and 2B4, that are usually expressed by NK cells (27-31). The proportion of type I NKT cells expressing specific NKRs is highly variable among healthy individuals $(1-85 \%)$ and can be altered upon interactions within the $\operatorname{TME}(31,56,74-78)$. In addition to the expression of NK- and T cell-associated cell surface markers, type I NKT cells express a wide range of inducible cytokineand chemokine receptors enabling them to respond to various signals (28-31, 79-81). For instance, type I NKT cells induce expression of the IL-2 receptor chain CD25 (IL-2RA) upon $\alpha$-GalCer-mediated activation $(28,29,31)$, primarily in the $\mathrm{CD}^{+}$type I NKT cell population (30). A different pattern is observed regarding the chemokine receptors CCR5, CCR6, CCR7, and CXCR6, which are all higher expressed on CD4 ${ }^{-}$type I NKT cells compared with $\mathrm{CD} 4^{+}$type I NKT cells $(27,29,30)$. Finally, type I NKT cells express various markers that are involved in a wide range of functionalities such as granzyme B, perforin, and CD95L, which play important roles in cytotoxicity $(29,31,82)$.

\section{Functional Type II NKT Cell Subsets}

So far, two distinct functional type II NKT cell subsets have been identified (Figure 1). $\mathrm{T}_{\mathrm{H}} 1$-like type II NKT cells secrete the pro-inflammatory cytokines IFN- $\gamma$ and TNF- $\alpha$ upon stimulation, whereas $\mathrm{T}_{\mathrm{H}}$ 2-like type II NKT cells secrete the regulatory cytokines IL-4 and IL-13 (19, 83-85). Murine studies showed that the cytokine profile of type II NKT cells can be influenced in the same way as has been observed for type I NKT cells (83), suggesting plasticity of type II NKT cell subsets as well.

\section{Identification of Type II NKT Cell Subsets}

In contrast to type I NKT cells, no specific methods exist to identify the entire type II NKT cell population due to the lack of specific markers. However several mouse models have been developed to study the role of type II NKT cells in cancer in vivo. These models include J $\alpha 18^{-/-}$mice, without type I NKT cells, and CD1d ${ }^{-/-}$mice that lack both type I and type II NKT cells (86-88). Another approach to study type II NKT cells in both mice and humans is by using sulfatide-loaded CD1d multimers $(19,84,89,90)$. However, this approach has not been widely used due to the unstable nature of sulfatide-loaded CD1d complexes. Furthermore, since not all type II NKT cells are sulfatide reactive, this method excludes a significant proportion of type II NKT cells $(83,89)$. As a result, the phenotype and function of type II NKT cells remain largely elusive, and new methods are essential to characterize this cell population in further detail.

\section{NKT-Like Cells}

In many studies, NKT cells are identified with flow cytometry using a combination of anti-CD3 and anti-CD56 $\mathrm{mAb}(31,81$, 91-94). Although it is likely that the $\mathrm{CD}^{+} \mathrm{CD}^{+} 6^{+}$cell population includes CD1d-restricted NKT cells, it has to be taken into consideration that conventional $\mathrm{T}$ cells have been reported to express NK-cell markers as well, including CD56 (17, 31, 79, 80). Since it is unclear whether $\mathrm{CD}^{+} \mathrm{CD}^{2} 6^{+}$cells are $\mathrm{CD} 1 \mathrm{~d}$ restricted, this population is often referred to as "NKT-like." An additional marker is essential to determine which part of the NKT-like cells are true NKT cells and which are not. Besides, only a small part of the type I NKT cell population expresses CD56 (29). Hence, a significant proportion of type I NKT cells is excluded from analyses when using the combination of anti-CD3 and anti-CD56 mAb. NKT-like cells express costimulatory-, cytokine-, and chemokine receptors, and NKRs that are also expressed by type I NKT cells $(27-31,81)$. Exceptions are killer-cell Ig-like receptors (KIRs) that provide either inhibitory or stimulatory signals upon interaction with human leukocyte antigen (HLA) molecules $(31,95,96)$. KIRs are primarily expressed by NKT-like cells, and not by type I NKT cells.

In conclusion, different functional NKT cell subsets can be identified within the type I and type II NKT cell populations. Although type I NKT cells are characterized in detail, type II NKT cells are not due to lack of specific markers. Studies so far suggest that the expression levels of cell surface markers on type I NKT cells are highly variable among healthy individuals. Interestingly, murine studies showed that expression patterns of 
type I NKT cell surface markers are modulated upon cell-cell interaction and/or interaction with signaling molecules $(74,76)$. These phenotypical modulations adapt the functional capabilities of the NKT cells, including the production of specific cytokines upon activation. These data indicate a high degree of NKT cell plasticity and that type I NKT cells (and probably type II NKT cells as well) are able to switch between different phenotypi$\mathrm{cal} /$ functional subsets. Studies on human NKT cells are needed to support this hypothesis.

\section{ACTIVATION OF NKT CELLS}

Due to expression of both NK- and T cell-associated functional molecules, NKT cells can be activated by mechanisms utilized by both NK- and T cells.

\section{Activation via T Cell-Like Mechanisms}

First, NKT cells can be activated via their TCR in a T celllike manner via recognition of glycolipids in the context of CD1d molecules $(61,97)$. CD1d is primarily expressed by antigen-presenting cells (APC) but has also been reported to be expressed by some epithelial, parenchymal, and vascular smooth muscle cells $(98,99)$. Importantly, APC are able to present both exogenous and endogenous glycolipids in the context of CD1d (Figure 2). Exogenous microbial- and non-microbial-derived glycolipids enter APC via different mechanisms as thoroughly reviewed by Bendelac et al. (100) and Barral and Brenner (101). For instance, exogenous glycolipids can be captured by the mannose receptor, or alternatively, insert themselves directly into the cell membrane of APC, upon which they undergo endocytosis. Furthermore, exogenous glycolipids may enter APC with very

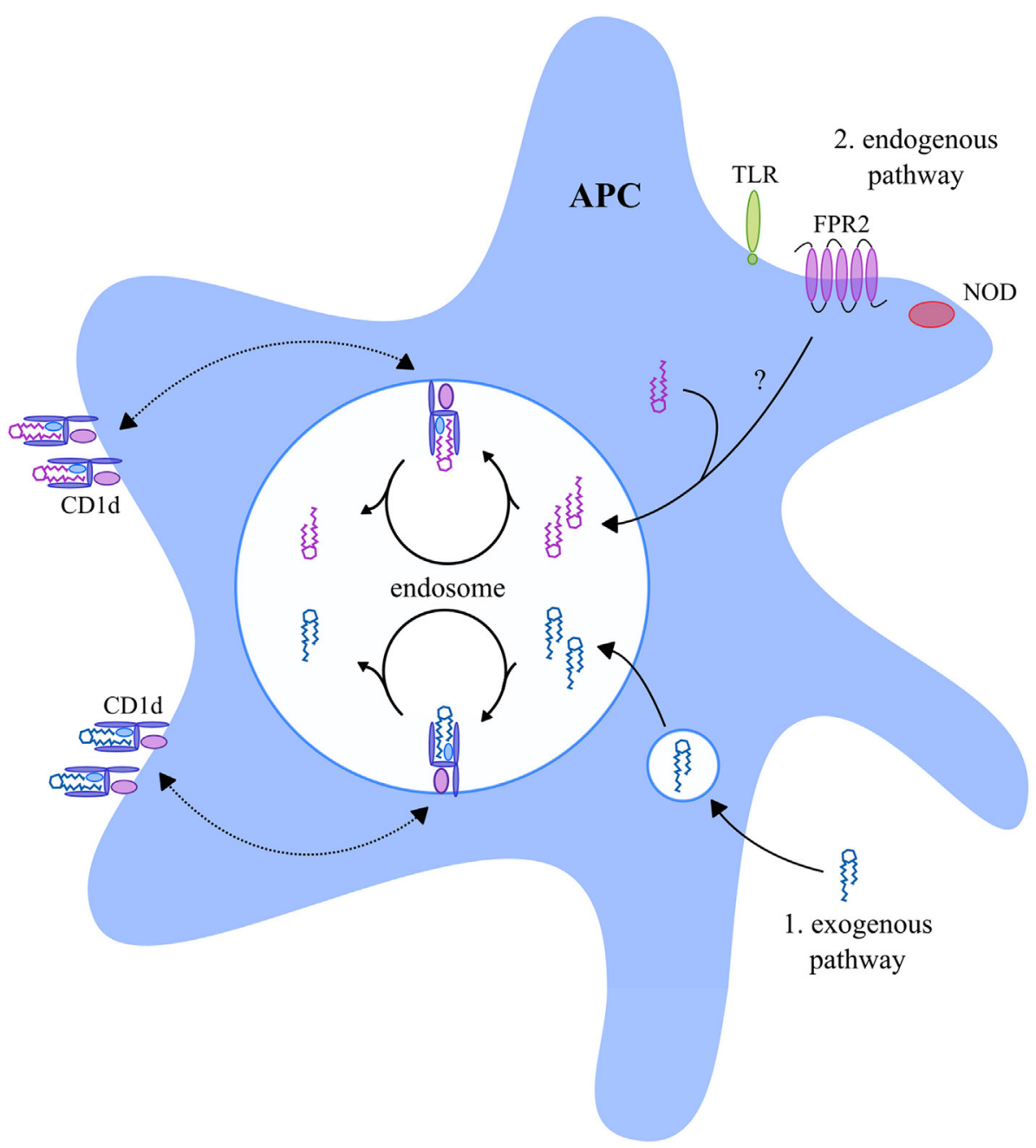

FIGURE 2 | CD1d-presented glycolipids in APC. APC present exogenous and endogenous glycolipids in the context of CD1d. During endosomal trafficking, CD1d molecules relocate from the cell membrane toward a late endosome where the bound glycolipid antigens are removed from CD1d and replaced by new glycolipid antigens. Exogenous glycolipids (indicated in blue) enter the APC late endosome via endocytosis or phagocytosis (1). Endogenous glycolipids (indicated in purple) enter the late endosome as a result of NOD, FPR2, or TLR signaling (2), but the exact mechanism is unknown. The exogenous and endogenous glycolipids are loaded into CD1d molecules upon which they relocate back to the cell membrane. Abbreviations: APC, antigen-presenting cells; NOD, nucleotide-binding oligomerization domain; FPR2, formyl peptide receptor 2; TLR, toll-like receptor. 
low-density lipoprotein particles via the low-density lipoprotein (LDL) receptor, or via phagocytosis. Finally, scavenger receptors can mediate internalization of apoptotic cells and modified LDL, which also leads to entering of exogenous glycolipids into APC. During endosomal trafficking, CD1d molecules relocate from the cell membrane toward a late endosome where the bound glycolipids are removed from CD1d and replaced by new glycolipids (Figure 2) $(102,103)$. Thereafter, the CD1d molecules relocate back to the cell membrane. In addition, APC also present endogenous glycolipids in the context of CD1d (Figure 2). For instance, activation of nucleotide-binding oligomerization domain-1 and -2 intracellular pattern recognition receptors by bacteria, or activation of formyl peptide receptor 2 by serum amyloid A-1, results in loading of endogenous glycolipids into CD1d molecules during endosomal CD1d trafficking (Figure 2) (104, 105). Furthermore, toll-like receptor signaling upon stimulation with lipopolysaccharide was suggested to result in the loading of endogenous glycolipids into CD1d molecules $(100,106)$. The exact mechanism of how these signaling pathways lead to the loading of endogenous glycolipids into CD1d is, however, unknown.

In contrast to TCRs on conventional $\mathrm{T}$ cells that recognize specific peptides presented by MHC class I or II, the Vo24J 18 TCR present on type I NKT cells recognizes a diversity of glycolipids that are presented by CD1d molecules. For instance, type I NKT cells recognize glycosphingolipids, $\alpha$-galactosyldiacylglycerols, diacylglycerols, and phospholipids derived from mycobacteria in addition to $\alpha$-GalCer (107-111). Furthermore, type I NKT cells can be activated upon encountering the self-glycolipids isoglobotrihexosylceramide and $\beta$-glucosylceramide $(11,112)$. In addition, type II NKT cells have been reported to recognize the self-glycolipids sulfatide and $\beta$-glucopyranosylceramide, as well as lysophospholipids and microbial lipids $(19,83,89,113,114)$. As a consequence of their diverse TCR repertoire, different type II NKT cell subsets exist, recognizing different lipids $(19,85)$.

Activated NKT cells are able to kill tumor cells directly in a CD1d-dependent manner (115). This antigen-specific cytotoxicity is CD95/CD95L dependent, unlike NK- and T cells that predominantly use perforin/granzyme-mediated mechanisms (115). Upon activation via their TCR in a CD1d-dependent manner, NKT cells rapidly expand and secrete a range of cytokines $(68,116-120)$. Crowe et al. reported $\sim 10$-fold expansion of type I NKT cell numbers in the murine spleen 2-3 days after injection with $2 \mu \mathrm{g} \alpha$-GalCer in mice (116). Besides, $\sim 7$ - and $\sim 3$-fold type I NKT cell expansion was reported in the liver and bone marrow of mice 2-3 days after $\alpha$-GalCer injection, respectively (116). Due to their memory-activated phenotype (69), NKT cells have the ability to respond quickly upon encountering an antigen. Within an hour after injection with $\alpha$-GalCer, a burst of cytokines can be detected in mice. For instance, studies reported maximal levels of IFN- $\gamma^{+}$ and IL- $4^{+}$murine liver- and splenic-derived type I NKT cells within $2 \mathrm{~h}$ after $\alpha$-GalCer activation in vivo $(116,117)$. In addition, high IFN- $\gamma(400 \mathrm{pg} / \mathrm{ml})$ and IL-4 $(1,500 \mathrm{pg} / \mathrm{ml})$ levels were detected in the serum of these mice $90 \mathrm{~min}$ after injection with $100 \mathrm{ng} / \mathrm{ml}$ $\alpha$-GalCer (117). Although the percentage of IL- $4^{+}$splenic-derived type I NKT cells dropped to baseline levels $16 \mathrm{~h}$ after injection of mice with $2 \mu$ g $\alpha$-GalCer, elevated IFN- $\gamma^{+}$type I NKT cells could still be detected after $72 \mathrm{~h}$ (116). In conclusion, NKT cells rapidly secrete a range of cytokines following activation with $\alpha$-GalCer.

\section{Activation via NK Cell-Like Mechanisms}

NKT cells seem to behave similar to NK cells when it comes to their activation. Like in NK cells, activation is dependent on the balance between inhibitory and stimulatory signals obtained via NKRs and KIRs $(121,122)$. As discussed earlier, phenotype studies showed that NKT cells also express a wide range of these receptors (27-31). Activating NKRs are able to recognize a variety of MHC-like molecules and cellular targets often referred to as "stress proteins." For instance, the NKG2D receptor recognizes MHC class I-like molecules (MIC) A and B and unique longbinding proteins (123), whereas DNAM-1 recognizes the poliovirus receptor and Nectin-2 (124). Besides, NKT cells express KIRs, with less well-defined ligands, that provide activating signals (125-128). Furthermore, NKT cells express NKRs and KIRs that provide inhibitory signals upon binding with HLA molecules (129-134). When the balance of signals is shifted toward activation, an NKT cell is activated, resulting in cytokine production as well as direct killing of tumor cells in a CD1d-independent manner (Figure 3). Interestingly, studies showed that inhibitory

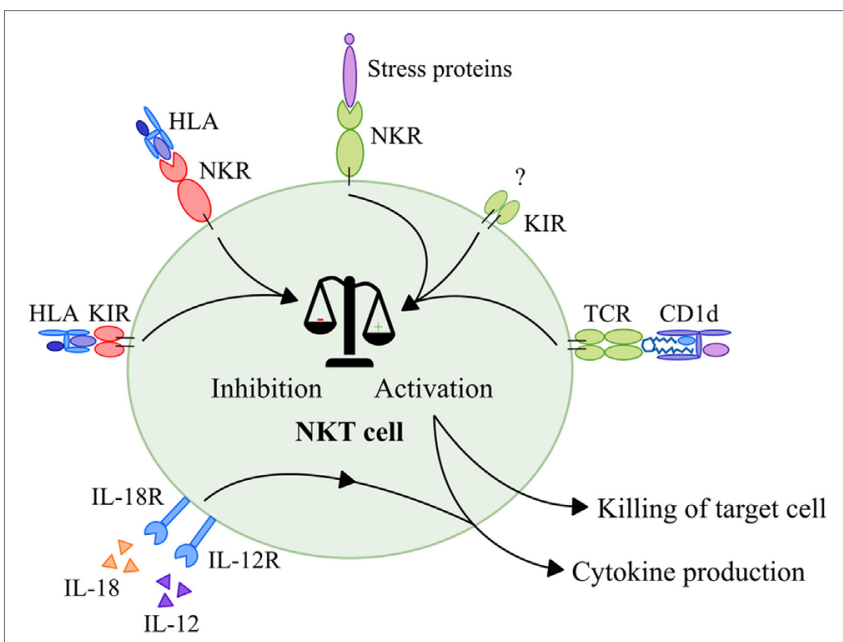

FIGURE 3 | Activation of NKT cells. Activation of NKT cells is dependent on a balance between activating and inhibitory signals. First of all, NKT cells receive activating signals via their TCR that recognize glycolipids in context of CD1d. Second, NKT cells receive activating signals in a CD1d-independent manner via NKRs upon interaction with stress proteins such as MIC-A and MIC-B, ULBPs, Nectin-2, or MLL5 proteins. In addition, NKT cells receive activating signals in a CD1d-independent manner via KIRs with merely unknown ligands. Inhibitory NKRs and KIRs that recognize HLA molecules provide inhibitory signals that are able to disrupt both TCR and NKR signaling. When the balance is skewed toward activation, NKT cells produce and secrete high amounts of cytokines. In addition, NKT cells that are activated via this mechanism are able to kill target cells directly via activation of their TCRs and NKRs. Finally, NKT cells - like NK cells - can be activated by a combination of IL-12 and IL-18 which leads to production of cytokines. Abbreviations: NKT, natural killer T; TCR, T cell receptor; NKR, natural killer receptor; MIC, major histocompatibility complex I-like molecules; ULBP, unique long-binding protein; MLL5, mixed-lineage leukemia-5; KIR, killer-cell Ig-like receptor; HLA, human leukocyte antigen; NK, natural killer. 
signals provided by KIRs and/or NKRs were able to interrupt TCR signaling in conventional T cells without CD1d restriction (31, 130, 131, 133). Since NKT cells express similar functional receptors, it is likely that similar interruption of TCR signaling also occurs in NKT cells (Figure 3). In addition, a part of the NKT cell population expresses the low affinity Fc receptor CD16 which is known to induce antibody-dependent cytotoxicity when present on NK cells (135). This phenomenon has, however, not been studied as yet in relation to NKT cells. In conclusion, NKT cells can be activated via different NK- and T cell-associated mechanisms that lead to immediate killing of tumor cells and secretion of large amounts of cytokines that have a major influence on the immune system.

Finally, studies showed that NKT cells-like NK cells-can also be activated by IL-12 in combination with IL-18 via cytokine receptors in a CD1d-independent manner (Figure 3) (136-138). These cytokines are secreted by, i.e., active macrophages or dendritic cells (DCs) (139-141). Upon interaction with IL-12 and IL-18, NKT cells secrete high amounts of IFN- $\gamma$, as also observed after CD1ddependent and NKR-mediated activation $(127,136,137,142)$.

\section{NKT Cell Anergy}

Importantly, murine studies have indicated that overstimulation and chronic activation of type I NKT cells with $\alpha$-GalCer via TCR-CD1d interaction may result in NKT cell death and induction of anergy $(116,143-147)$. This resembles the response of conventional T cells upon activation in the TME in presence of coinhibitory stimuli or checkpoint molecules like programmed death-ligand 1 (PD-L1) $(148,149)$. Upon binding with $\alpha$-GalCer in the context of CD1d, type I NKT cells downregulate their TCR and NKR expression and upregulate the inhibitory molecules programmed cell death protein 1 (PD-1) and B- and T-lymphocyte attenuator (144, 146, 150), resulting in hyporesponsiveness. Furthermore, chronic stimulation of type I NKT cells with $\alpha$-GalCer in vivo resulted in activation-induced cell death (AICD) via upregulation of the death receptor CD95, thereby contributing to active depletion of type I NKT cells $(151,152)$. This is most likely a feedback mechanism used by NKT cells to prevent tissue damage. Anergy induced by $\alpha$-GalCer also resulted in impaired proliferation and production of IFN- $\gamma$ by type I NKT cells upon $\alpha$-GalCer restimulation. By contrast, anergic type I NKT cells retained their capacity to produce $\mathrm{T}_{\mathrm{H}} 2$-associated cytokines (144). Moreover, pretreatment with $\alpha$-GalCer skewed type I

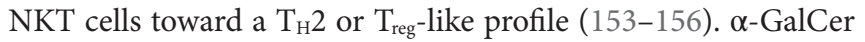
pretreated type I NKT cells acquired characteristics of regulatory cells in vivo, including production and secretion of IL-10, which is known to induce and maintain an immunosuppressive TME (153-155). Chronic stimulation of NKT cells in the TME might therefore contribute to immune escape in cancer patients.

\section{THE REGULATORY FUNCTION OF NKT CELLS}

Depending on which functional NKT cell subsets are involved, both type I and type II NKT cell subsets are able to either skew the immune response toward inflammation or toward tolerance. Activated NKT cells shape the TME via modulation of cells from both the innate and adaptive immune system (Figure 4), thereby implementing an important regulatory function.

NKT cells are unique in the sense that they can activate and induce full maturation of DC $(139,140,157)$. This maturation requires direct interaction of DC with NKT cells via the TCRCD1d complex in combination with CD40/CD40L costimulation. As a result, DC produce IL-12, which further drives IFN- $\gamma$ production by $\mathrm{T}_{\mathrm{H}} 1$-like NKT cell subsets. By contrast, IL-13 and IL-4, produced by $\mathrm{T}_{\mathrm{H}} 2$-like NKT cell subsets, indirectly suppress $\mathrm{T}$ cell function and drive $\mathrm{T}_{\mathrm{H}} 2$ differentiation, respectively (49, 158-160). IL-10, produced by $\mathrm{T}_{\text {reg-like type I NKT cells drives }}$ $\mathrm{T}$ cell differentiation toward $\mathrm{T}_{\text {regs }}$, thereby contributing to the establishment of an immunosuppressive TME (161). Finally, the IL-21 producing $\mathrm{T}_{\mathrm{FH}}$-like type I NKT cell subset interacts directly with B cells that present the same glycolipid in context of CD1d as used to activate the NKT cells, resulting in fast immunoglobulin production and affinity maturation $(53,162-165)$.

In addition to production of large amounts of cytokines as discussed earlier, NKT cells secrete a range of chemokines upon activation, including RANTES, Eotaxin, MIP- $1 \alpha$, and MIP-1 $\beta$, that lead to the attraction of NK cells, neutrophils, and monocytes toward the inflammatory microenvironment (166). IFN- $\gamma$ secreted by $\mathrm{T}_{\mathrm{H}} 1$-like NKT cell subsets then leads to the local activation of NK cells, neutrophils, and macrophages (167-169). Furthermore, granulocyte macrophage colony-stimulating factor (GM-CSF), IFN- $\gamma$, and IL-4 secreted by NKT cells may shift the functional capacity of monocytes toward a more DC-like phenotype which contributes to the activation of $\mathrm{T}$ cells and, indirectly, B cells $(170,171)$. NKT cells are also able to reverse the phenotype of immune suppressive neutrophils by reducing secretion of IL-10 and enhancing IL-12 production in a CD1ddependent manner (105).

In conclusion, NKT cells are able to rapidly respond to a wide variety of glycolipids and stress proteins using T- and NK cell-like mechanisms, respectively. Although NKT cells comprise a minor immune cell subset in most organs, they have a major effect on immune regulation since they can skew an immune response toward inflammation or tolerance in a very short time by secreting pro- or anti-inflammatory cytokines. Besides, NKT cells have the ability to kill tumor cells directly upon activation but, probably reflected by their relative low numbers, NKT cells primarily have a regulatory function. Based on this information, it is clear that NKT cells are not just cells with NK- and T cell properties: by combining characteristics of both cell types, NKT cells are able to add unique functions to the immune response. NKT cells may play a uniquely central role during the very first steps in the initiation of an antitumor immune response. The main reasons are the ability of NKT cells to respond fast by influencing other immune cells, resulting in amplification or dampening of the immune response.

\section{THE IN VITRO AND IN VIVO ANTITUMOR ACTIVITY OF NKT CELLS}

\section{Type I NKT Cells in Tumor Immunity}

Twenty years ago, it was first reported that the glycolipid $\alpha$-GalCer, discovered in marine sponges, had potent antitumor activity in vivo (172-174). Mice that were intravenously inoculated with 


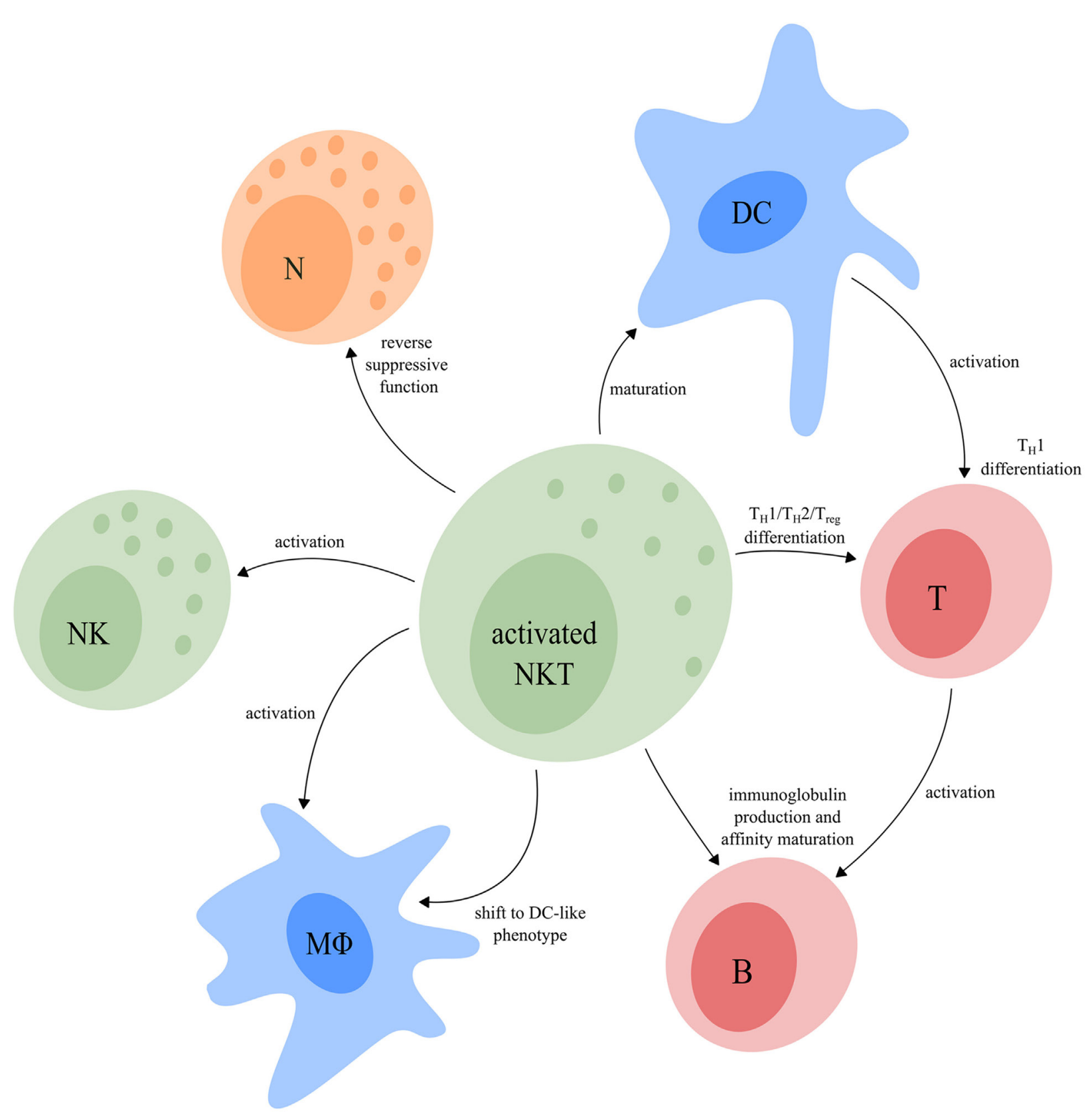

FIGURE 4 | The regulatory function of activated NKT cells. Upon activation, NKT cells have a major influence on other immune cells. NKT cells can induce full maturation of DC upon which they activate $T$ cells and induce $T_{H} 1$ differentiation. Activated $T$ cells interact with $B$ cells resulting in their activation, as well as production of immunoglobulins and affinity maturation. The $T_{F H}$ type I NKT cell subset provides cognate help for B cells which promotes the production of immunoglobulins and affinity maturation. In addition, NKT cells can reverse the phenotype of immune suppressive neutrophils. Upon activation, NKT cells are also able to activate NK cells and macrophages and induce a functional shift of monocytes toward a DC-like phenotype. Finally, NKT cells can drive T cell differentiation

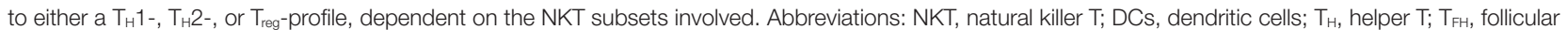

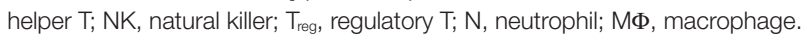

B-16 (melanoma) or intraperitoneally inoculated with EL-4 (lymphoma) cells showed a significantly prolonged lifespan after injection with $\alpha$-GalCer, with a stronger potency than the typical chemotherapeutic agent mitomycin C (172). A role for NKT cells in this antitumor activity was suggested a few years later when it was discovered that $\alpha$-GalCer is recognized by type I NKT cells via their TCR in the context of CD1d, leading to their activation (175). Thereafter, studies showed that type I NKT cells were the key effectors of antitumor responses in a murine B-16 melanoma metastasis model (176-178). For instance, Toura et al. reported 
that activation of type I NKT cells via injection with $\alpha$-GalCerpulsed-DC resulted in complete eradication of established B-16 melanoma liver metastases (178). Administration of $\alpha$-GalCer to activate type I NKT cells even prevented primary tumor formation in different in vivo models (179). By contrast, mice lacking type I NKT cells were more prone to chemical or p53 loss-induced tumor development (180-182). Recently, it was reported that type I NKT cells also play a role in preventing metastatic disease in a 4T1 mammary carcinoma model (183). Upon resection of the primary breast tumors, treatment with $\alpha$-GalCer-pulsed-DC limited formation of tumor metastases, prolonged survival, and provided curative outcomes in $\sim 45 \%$ of the mice. Thereafter, it was shown that $\alpha$-GalCer-pulsed-DC could also be combined with the chemotherapeutics cyclophosphamide or gemcitabine to enhance survival of mice with metastatic disease (184). Importantly, studies showed that the anti-metastatic effect of $\alpha$-GalCer was impaired in NK cell-depleted or IFN- $\gamma$-deficient mice $(185,186)$. Smyth et al. showed that IFN- $\gamma$ production by type I NKT cells and subsequent IFN- $\gamma$ production by NK cells was crucial for $\alpha$-GalCer-mediated tumor protection (177). In line with these results, it was observed that the $\mathrm{T}_{\mathrm{H}}$ 2-skewing synthetic $\alpha$-GalCer-analog OCH provided less tumor protection in the CT26 mouse model compared with $\alpha$-GalCer (187). By contrast, studies reported that analogs of $\alpha$-GalCer, which skewed the cytokine profile of type I NKT cells toward $\mathrm{T}_{\mathrm{H}} 1$, provided superior protection against metastases formation compared with $\alpha$-GalCer (188-190). This implicates a crucial role for type I NKT cells with a $\mathrm{T}_{\mathrm{H}} 1$ cytokine profile in antitumor activity.

After the discovery of the important role of activated type I NKT cells in antitumor responses in vivo, studies focused on the mechanisms used by these NKT cells to eradicate tumor cells. As mentioned earlier, CD1d is primarily expressed by APC, although malignant hematopoietic cells have also been reported to express CD1d on their cell membrane $(4,191-193)$. In addition, there is evidence that solid tumors also express CD1d, including renal cell and colorectal carcinomas $(194,195)$. Upon activation with $\alpha$-GalCer, type I NKT cells were able to kill CD1d ${ }^{+}$tumor cells in a CD1d-dependent manner (4, 191-193, 195). To kill tumor cells directly via CD1d interaction, they need to present glycolipids that can be recognized by NKT cells. There is evidence from murine studies that type I NKT cells can be activated by tumorderived glycolipids that are cross-presented by APC in the context of CD1d (196-199). However, until now, the nature of tumor glycolipids that are recognized by NKT cells remains poorly elucidated. Since the cytolysis and eradication of tumor cells via type I NKT cells was shown to be dependent on CD1d expression on their cell surface, it was suggested that CD1d expression might be a predictor of whether $\alpha$-GalCer-activated type I NKT cells are able to eradicate tumor cells or not $(3,4)$. However, other studies showed that CD1d $\mathrm{d}^{-}$hematopoietic cells could also be killed directly by type I NKT cells, for instance, via NKG2D activation $(5,200,201)$. This illustrates that type I NKT cells, like NK cells, are able to kill tumor cells via NKR activation, even in the absence of CD1d. Moreover, although type I NKT cells are capable of killing tumor cells directly, they primarily mediate antitumor activity via the activation of downstream immune effector cells as demonstrated by human and mouse studies $(4,177,202,203)$.
Especially $\mathrm{T}_{\mathrm{H}} 1$-like type I NKT cells play an important role in this antitumor activity via secretion of large amounts of IFN- $\gamma$, which leads to generation of tumor-specific $\mathrm{CD}^{+}$cytotoxic T cells, and rapid activation of NK cells $(4,177,188,202-204)$.

\section{Type II NKT Cells in Tumor Immunity}

In contrast to type I NKT cells, only limited information is available regarding the role of type II NKT cells in cancer. However, some in vivo models provided important information. In general, type II NKT cells are associated with immunosuppression and tumor progression. For instance, murine carcinoma and lymphoma models showed that the tumor burden of $\mathrm{CD}^{-/-}$mice, without type I and type II NKT cells, was lower compared with J $\alpha 18^{-/-}$mice that lack type I NKT cells only (86-88). Injections with sulfatide increased the number of tumor nodules in a CT26 colon carcinoma lung metastasis mouse model via activation of type II NKT cells (205). Besides, administration of sulfatide abrogated the protective effect of $\alpha$-GalCer-activated type I NKT cells against tumor development. Type II NKT cells were reported to produce IL-13 through the IL-4R-STAT6 pathway, which was necessary for downregulation of tumor immunosurveillance in a 15-12RM fibrosarcoma mouse model (49). Thereafter, it was shown that IL-13 induced TGF- $\beta$-secreting myeloid-derived suppressor cells (MDSCs) in vivo that inhibited tumor-specific $\mathrm{T}$ cells $(158,206)$. A role for MDSC in inhibition of antitumor immunosurveillance was supported by the study of Renukaradhya et al. that showed large numbers of these cells at the tumor site of B cell lymphoma-bearing J $\alpha 18^{-1-}$ mice without type I NKT cells (87). This implicates an important role for type II NKT cells in suppression of immunosurveillance in cancer. Although Zhao et al. showed in an in vivo murine model that activation of type II NKT cells with CpG oligodeoxynucleotides resulted in antitumor activity of these cells via the production of $\operatorname{IFN}-\gamma(83,207)$. The involvement of IFN- $\gamma$ implies that type II NKT cells are able to contribute to antitumor responses, but only when the $\mathrm{T}_{\mathrm{H}} 1$-like subset is involved.

In conclusion, a crucial role is implicated for type I NKT cells with a $\mathrm{T}_{\mathrm{H}} 1$ cytokine profile in antitumor activity. Although it is generally accepted that the type II NKT cell population promotes tumor growth, there is evidence that $\mathrm{T}_{\mathrm{H}} 1$-like type II NKT cells can be involved in antitumor responses. Hence, the role of NKT cells in malignancies is highly dependent on which functional type I or type II NKT cell subsets are involved.

\section{THE FUNCTION AND PHENOTYPE OF NKT CELLS IN PATIENTS DIAGNOSED WITH CANCER}

Several human studies have addressed the presence, function, and/or phenotype of NKT cells in cancer patients. Here, we will focus on both tumor-infiltrating and -circulating NKT cells.

\section{Tumor-Infiltrating NKT Cells}

Studies showed a difference in the presence of NKT cells between tumor tissue and non-tumor tissue. The frequency of type I NKT cells was reported to be higher in intrahepatic malignant 
tumors and colorectal carcinomas compared with normal liver tissue and normal mucosa, respectively $(208,209)$. The opposite pattern was reported by Kenna et al. who showed a significantly lower presence of liver-infiltrating type I NKT cells in colorectal liver metastases compared with healthy liver tissue (35). In addition, several studies showed a correlation between infiltrating NKT cell numbers and clinical outcome. High numbers of tumor-infiltrating type I NKT cells correlated with a relatively good clinical outcome in patients diagnosed with colorectal cancer and neuroblastoma $(209,210)$. High density of NK/NKT cells was also associated with prolonged overall survival in periampullary adenocarcinoma (including pancreatic cancer) patients (211). Accordingly, absence of infiltrating type I NKT cells and low numbers of infiltrating NKT-like cells correlated with poor patient survival and disease progression in neuroblastoma and gastric cancer, respectively $(91,212)$.

The function and phenotype of infiltrating type I NKT cells was addressed in studies on hepatocellular carcinoma, colorectal cancer, and neuroblastoma $(35,209,212)$. Lower expression of CD56 and CD161 was reported on infiltrating type I NKT cells in tumor-bearing livers compared with normal livers (35). In addition, in a study on colorectal cancer, expression of the activation markers CD69L and FasL was reported on a larger fraction of infiltrating type I NKT cells in tumor tissue compared with normal mucosa (209). Tumor-infiltrating type I NKT cells expressed IFN- $\gamma$ and granzyme B, but the authors did not compare the expression of these markers to that of type I NKT cells in normal mucosa (209). In addition, it was observed that type I NKT cell infiltration in neuroblastomas was associated with CCL2 expression on tumor cells, indicating that expression of homing receptors on tumors was essential for infiltration of type I NKT cells in neuroblastoma (212). Furthermore, in two studies $(91,92)$ the function and phenotype of infiltrating NKT-like cells in tumors were described. Peng et al. reported impaired effector function of infiltrating NKT-like cells in gastric cancer-derived tumor tissue compared with non-tumor tissue, characterized by decreased expression of IFN- $\gamma$, TNF- $\alpha$, granzyme B, and Ki-67 (91). Furthermore, this study also showed decreased expression of the lymphocyte proliferation marker CD69, the homing receptors CXCR3 and CCR5, and the NKRs NKG2D and DNAM-1 on NKT-like cells in tumor tissue compared with non-tumor tissue. In addition, a study on patients with hepatocellular carcinoma showed that NKT-like cells in tumor tissue expressed FOXP3 and lost expression of IFN- $\gamma$ and perforin compared with NKT-like cells in non-tumor tissue (92).

In conclusion, tumor-infiltrating type I NKT cells and NKTlike cells may express less activating receptors, homing receptors and proliferation markers and produce lower amounts of $\mathrm{T}_{\mathrm{H}} 1$ associated cytokines compared with type I NKT cells and NKTlike cells in healthy tissue, indicating tolerance and not antitumor activity.

\section{Circulating NKT Cells}

In addition, studies also showed altered function of circulating type I NKT cells in cancer patients. For instance, the number of circulating type I NKT cells was significantly decreased in patients with different cancers compared with healthy controls (213-221). In line with the results on infiltrating type I NKT cells, low circulating type I NKT cell numbers correlated with poor clinical outcome in patients with head and neck squamous cell carcinoma $(214,215)$. Interestingly, late-stage cancer patients presented with lower type I NKT cell numbers than early-stage cancer patients with oral squamous cell carcinoma or laryngeal cancer $(218,221)$, suggesting cancer-mediated depletion of NKT cells. After resection of the primary tumor, type I NKT cell numbers did not increase in patients with different cancer types $(213,220)$. By contrast, circulating NKT-like cell numbers were not decreased in patients diagnosed with laryngeal cancer, gastric cancer, or hepatocellular carcinoma $(91,92,220)$.

Besides being reduced in numbers, circulating type I NKT cells are often functionally impaired in patients $(216,218,219$, 222-224). For instance, circulating type I NKT cells derived from patients with prostate cancer or oral squamous cell carcinoma had a $\mathrm{T}_{\mathrm{H}} 2$-biased cytokine profile $(218,219)$. Furthermore, type I NKT cells obtained from patients with advanced cancer stages showed impaired cytokine production and proliferative capacity upon ex vivo activation with $\alpha$-GalCer $(216,219,222)$. In accordance with this observation, lower numbers of IFN- $\gamma$-producing type I NKT cells were observed in patients with colon carcinoma, head and neck cancer, breast cancer, or renal cell carcinoma compared with healthy controls (213). These changes in cytokine profile imply that type I NKT cells switched from a $\mathrm{T}_{\mathrm{H}} 1$ - toward a $\mathrm{T}_{\mathrm{H}}$ 2-like NKT cell subset.

In conclusion, reduced frequency of circulating NKT cells and altered phenotype, resulting in altered function, of both infiltrating and circulating NKT cells are often observed in cancer patients, especially in patients with late-stage disease. Since altered function was not observed in infiltrating NKT cells in healthy tissue, it can be argued that this altered function of NKT cells is cancer/TME mediated: tumors may suppress the immune system, and skew the cytokine profile of NKT cells from $\mathrm{T}_{\mathrm{H}} 1$ toward $\mathrm{T}_{\mathrm{H}} 2$ to escape from recognition and elimination. Although the mechanisms behind the cancer/TME-mediated altered function of NKT cells are not fully understood, studies suggested a role for metabolic derivative lactic acid (225), the production of soluble factors by tumors such as sMIC (226), and the expression of CD1d by tumors $(194,227)$.

\section{SHAPING THE TME BY NKT CELLS}

\section{Shaping the TME by $T_{H} 1$-Like NKT Subsets}

As discussed earlier, $\mathrm{T}_{\mathrm{H}} 1$-like NKT cells are promising candidates to initiate effective antitumor immune responses. $\mathrm{T}_{\mathrm{H}} 1$-like NKT cells might play an important role in antitumor responses by shaping the TME (Figure 5). For instance, they have been reported to colocalize with tumor-associated macrophages (TAM) with an M2-polarized phenotype that promote tumor growth and progression $(155,228)$. This colocalization resulted in CD1d-dependent killing of TAM that cross-presented tumor-derived glycolipids in vivo $(197,229)$. Furthermore, $\mathrm{T}_{\mathrm{H}} 1$-like NKT cells and secondary activated NK cells contributed to the inhibition of tumor angiogenesis by IFN- $\boldsymbol{\gamma}$ via suppression of M2-polarized TAM 


\section{anti-tumor response}

$\mathrm{T}_{\mathrm{H}}$ 1-like NKT subset
Tumor progression

NKT Chronic stimulation immune escape

$\mathrm{T}_{\mathrm{H}^{2}}$-/ $\mathrm{T}_{\text {reg-like NKT subsets }}$

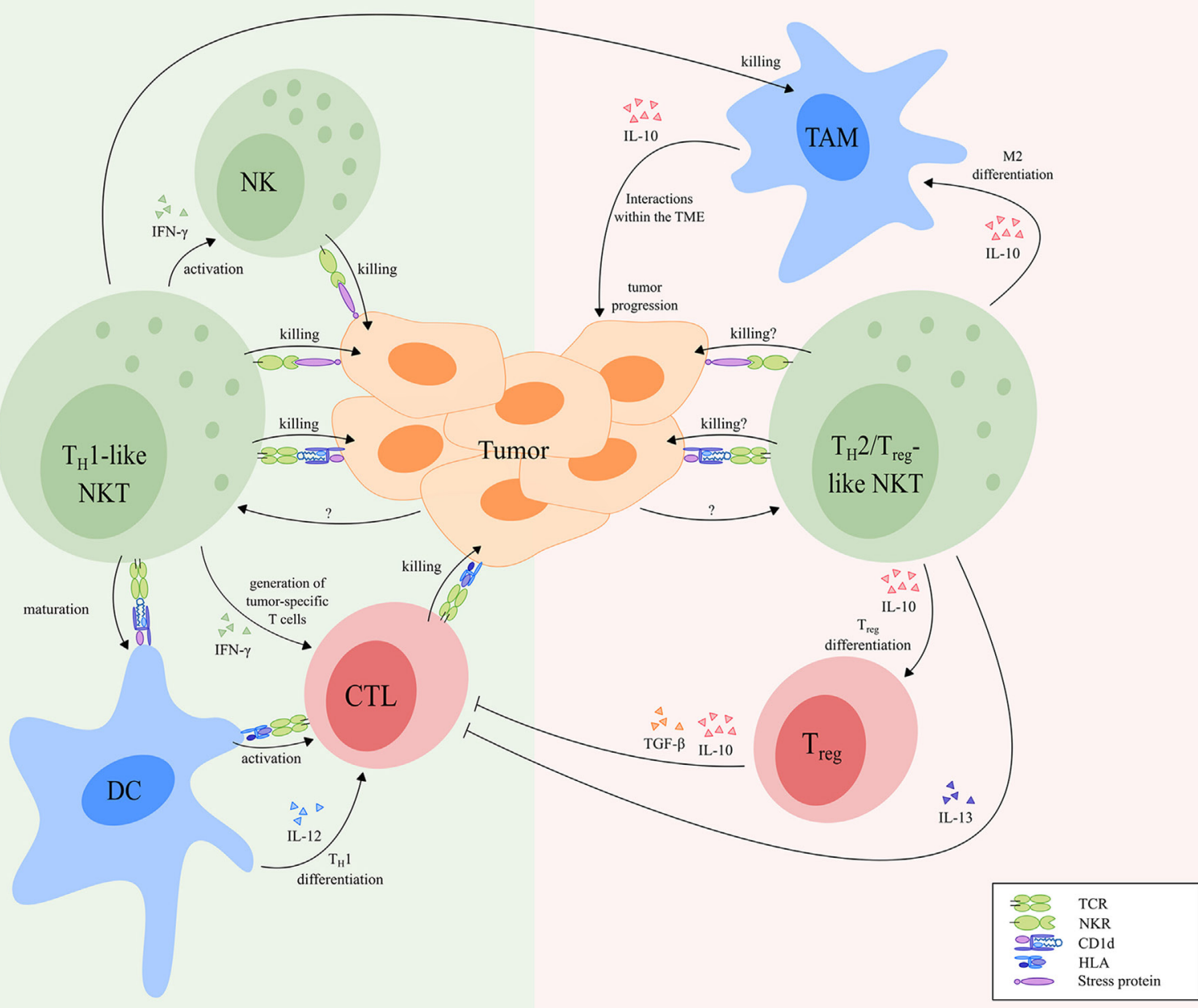

FIGURE 5 | The dual role of NKT cells in cancer. During early tumor development, $T_{H} 1$-like NKT cells may induce an effective antitumor response via direct killing of tumor cells upon interaction with stress proteins and CD1d molecules, respectively. In addition, activated $T_{H} 1$-like NKT cells secrete high amounts of IFN- $\gamma$, which may lead to generation of tumor-specific CD8 ${ }^{+}$cytotoxic T cells and rapid activation of NK cells that kill tumor cells. Besides, activated NKT cells can induce

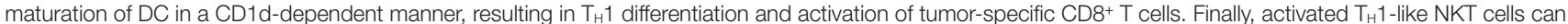
kill M2-polarized TAM in a CD1d-dependent manner, thereby preventing their tumor growth-promoting effects. During tumor progression, $T_{H} 1$-like NKT cells can become anergic and may switch to $T_{H} 2-/ T_{r e g}$-like NKT cell subsets that facilitate tumor progression and immune escape. For instance, $T_{\text {reg }}$-like NKT cells can promote differentiation of M2-polarized TAM and Tregs. Tregs inhibit tumor-specific T cells via cell-cell interactions, and secretion of IL-10 and TGF- $\beta$. In addition,

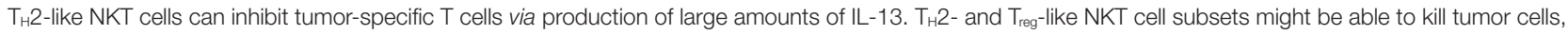
either via CD1d-dependent or CD1d-independent mechanisms. However, overstimulated NKT cells produce large amounts of immunosuppressive cytokines, resulting in a net effect of immunosuppression. Receptors that are known to be involved in NKT cell-mediated antitumor responses are indicated in the figure. The functional NKT cell subsets indicated in the figure can be both type I and type II NKT cells as illustrated in Figure 1. Abbreviations: NKT, natural killer T; $T_{H}$, helper T; NK, natural killer; DCs, dendritic cells; TAM, tumor-associated macrophages; $T_{\text {reg, }}$ regulatory T; TME, tumor microenvironment; NKR, natural killer receptor; TCR, T cell receptor; HLA, human leukocyte antigen.

$(230,231)$. Finally, Courtney et al. showed that type I NKT cells were able to kill CD1d ${ }^{+}$M2 TAM or polarize M2 TAM toward an M1-polarized phenotype via GM-CSF production (232). Hence, the presence of $\mathrm{T}_{\mathrm{H}} 1$-like type I NKT cells might minimize the presence of tumor growth-promoting M2-polarized TAM in the TME. On the other side, an immature tolerogenic DC subset 
has been described that produces reduced amounts of IL-12 and high amounts of IL-10, resulting in an immunosuppressive TME (233). As a result, tolerogenic DC skew differentiation of naïve $\mathrm{T}$ cells into $\mathrm{T}_{\text {regs }}$, which might lead to immune escape of tumor cells (234-236). Since $\mathrm{T}_{\mathrm{H}} 1$-like NKT cells are able to fully mature DC, the presence of immature tolerogenic DC might be minimized in tumors where sufficient numbers of these NKT cells are present. Importantly, $\mathrm{T}_{\mathrm{H}} 1$-like NKT cells are able to stimulate both tumor antigen-restricted $\mathrm{T}$ cells that recognize tumor cells with HLA expression and effector NK cells that eliminate tumor cells with low or absent HLA expression (234). In this way, immune escape of tumor cells might be prevented. In addition, as discussed earlier, tumors have been reported to express CD1d on their cell membrane $(194,195)$ and might therefore be killed in a CD1d-dependent manner. Besides, tumors are reported to express high cell surface densities of stress-related proteins that activate the NKRs NKG2D and DNAM-1 (237, 238), suggesting that these cells can also be killed in a CD1d-independent manner. HLA class I loss or downregulation has often been reported in tumors including carcinomas, sarcomas, neuroblastomas, and melanomas (239-242). Since inhibitory NKRs and KIRs prevent NKT cell activation upon interaction with HLA molecules (Figure 3), NKT cells might be able to directly kill tumor cells with low HLA expression, similar to NK cells. NKT cells may have, however, primarily a regulatory function, suggesting that the antitumor activity mediated by direct killing of tumor cells is of lesser importance.

\section{Shaping the TME by $T_{\mathrm{H}} 2-/ \mathrm{T}_{\text {reg }}$-Like NKT Subsets}

As discussed in the previous chapter, the phenotype and function of $\mathrm{T}_{\mathrm{H}} 1$-like subsets is frequently altered in patients. The NKT cell population in patients is skewed toward a $\mathrm{T}_{\mathrm{H}} 2$ profile, proliferative impaired and, in addition, reduced in size. These data indicate many similarities with overstimulated/anergic NKT cells. During cancer progression, NKT cells may be exposed to chronic stimulation, which is known to induce anergy and skew NKT cells toward immunosuppressive subsets. Moreover, chronic stimulation of NKT cells activates AICD, which might explain the reduced NKT cell population observed in cancer patients. Based on this hypothesis, we propose that $\mathrm{T}_{\mathrm{H}} 1$-like NKT cells induce an effective antitumor response during early tumor development and perhaps prevent further tumor development in many cases. However, in some cases, at some point during tumor progression, NKT cells become overstimulated. As a result, a part of the NKT cell population is deleted in cancer patients via AICD. In addition, the remaining NKT cells become hyporesponsive, or switch to $\mathrm{T}_{\mathrm{H}} 2-/ \mathrm{T}_{\text {reg }}$-like NKT cell subsets, thereby facilitating tumor progression and immune escape (Figure 5). $\mathrm{T}_{\mathrm{H}} 2$ - and $\mathrm{T}_{\text {reg- }}$-like NKT cell subsets do not produce IFN- $\gamma$ which is responsible for most of the antitumor effects of $\mathrm{T}_{\mathrm{H}} 1$-like NKT cells as discussed earlier. By contrast, $\mathrm{T}_{\mathrm{H}} 2-/ \mathrm{T}_{\text {reg }}$-like NKT cells produce large amounts of IL-13 and IL-10, respectively, that suppress the TME (i.e., via fibroblasts and MDSC), thereby indirectly stimulating tumor progression. In addition, $\mathrm{T}_{\text {reg }}$-like NKT cells promote differentiation of M2-polarized TAM and $\mathrm{T}_{\text {regs }}$ that are also able to suppress the TME via production of IL-10 $(154,155)$.
In contrast to $\mathrm{T}_{\mathrm{H}} 1$-like NKT cells, $\mathrm{T}_{\mathrm{H}}$-like NKT cells are not capable of inducing DC maturation and do therefore not induce activation of tumor-specific $\mathrm{T}$ cells (157). $\mathrm{T}_{\mathrm{H}} 2$-like NKT cell subsets further inhibit the activation of tumor-specific T cells via secretion of IL-13 $(49,158,159)$, while $\mathrm{T}_{\text {regs }}$ inhibit tumor-specific T cells via cell-cell interactions and secretion of IL-10 and TGF- $\beta$ $(243,244) . \mathrm{T}_{\mathrm{H}} 2$ - and $\mathrm{T}_{\text {reg }}$-like NKT cell subsets might still be able to kill tumor cells, either via CD1d-dependent or CD1dindependent mechanisms. However, overstimulated NKT cells produce large amounts of immunosuppressive cytokines, resulting in a net effect of immunosuppression. $\mathrm{T}_{\mathrm{H}} 2$ - and $\mathrm{T}_{\text {reg }}$-like NKT cell subsets, therefore, counteract the antitumor effects of $\mathrm{T}_{\mathrm{H}} 1$-like NKT cells and, in addition, actively promote tumor progression.

In conclusion, we discussed evidence supporting our hypothetical model (Figure 5) that $\mathrm{T}_{\mathrm{H}} 1$-like NKT cells are responsible for initiating effective antitumor immune responses during early tumor development. When NKT cells become overstimulated and anergic due to tumor progression, a part of the NKT cell population is deleted in cancer patients. In addition, the remaining NKT cells lose their antitumor function and start facilitating immune escape and tumor progression. In summary, we illustrated three problems regarding NKT cells in cancer patients. First, the numbers are lower compared with healthy individuals. Second, NKT cells are often anergic in cancer patients. Third, NKT cells are often skewed toward immunosuppressive $\mathrm{T}_{\mathrm{H}} 2$-like subsets.

\section{CURRENT NKT CELL-BASED IMMUNOTHERAPY FOR THE TREATMENT OF CANCER}

Because of their potential to induce effective antitumor responses in vivo, several NKT cell-based immunotherapies in humans have been developed over the past years as thoroughly reviewed by Nair and Dhodapkar (245). These immunotherapies primarily focused on activation and expansion of the type I NKT cell population.

For instance, a phase I clinical trial was executed in which intravenous (i.v.) injections of $50-4,800 \mu \mathrm{g} / \mathrm{m}^{2} \alpha$-GalCer were administered to 24 patients with different solid tumors (217). The majority of patients presented with reduced numbers of type I NKT cells at baseline (median 333 cells $/ \mathrm{ml} \mathrm{PB}$ ) compared with healthy donors (median 1,013 cells/ml PB). Following $\alpha$-GalCer administration, NKT cells disappeared from the circulation within $24 \mathrm{~h}$. Although not investigated in details in this study, recovery of NKT cell numbers was not observed within a week. Furthermore, increased serum levels of TNF- $\alpha$ and GM-CSF were detected in five patients and increased serum IFN- $\gamma$ levels were detected in one patient after $\alpha$-GalCer administration. A phase II trial using administration of $\alpha$-GalCer was not executed. In addition, clinical trials were conducted in which patients were injected with $\alpha$-GalCer-pulsed autologous DC (246-252). These injections resulted in expansion of the type I NKT cell population in some patients (246-252). For instance, Chang et al. reported $>100$-fold expansion of type I NKT cells in 5 patients upon i.v. injections with $5 \times 10^{6} \alpha$-GalCer-pulsed DC (247). Besides NKT cell expansion, treatment with $\alpha$-GalCer-pulsed DC also 
increased the systemic levels of IFN- $\gamma$ in patients (246-252). Treatment did, however, not result in a clinical tumor response in the majority of patients (246-252). In addition, a phase II study reported stable disease in 5 of 17 patients with non-small cell lung cancer (NSCL) upon i.v. administration of $\alpha$-GalCer-pulsed IL-2/ GM-CSF-cultured PBMC $\left(1 \times 10^{9}\right.$ cells $\left./ \mathrm{m}^{2}\right)(251)$. Patients with increased IFN- $\gamma$ producing $\mathrm{T}_{\mathrm{H}} 1$-like type I NKT cells after treatment showed a prolonged median survival time compared with non-responsive patients. These data indeed indicate a crucial role for $\mathrm{T}_{\mathrm{H}} 1$-like type I NKT cells in antitumor immune responses and emphasize the essential need for expansion of this NKT cell population in cancer patients. Hence, immunotherapeutic approaches focused on skewing NKT cells toward a $\mathrm{T}_{\mathrm{H}} 1$ profile should be developed.

In later clinical trials, ex vivo-activated type I NKT cells were adoptively transferred to patients diagnosed with NSCL, advanced melanoma, or head and neck squamous cell carcinoma, in some cases in combination with $\alpha$-GalCer-pulsed APC (253-256). In this therapy, PBMC obtained from the patient, i.e., by leukapheresis, were cultured in the presence of IL-2 and $\alpha$-GalCer to facilitate proliferation and activation of the type I NKT cell population. Thereafter, the ex vivo-activated type I NKT cells were administered to the patients. Phase I and II clinical trials were conducted in which patients with head and neck carcinomas received nasal submucosal injections of $1 \times 10^{8}$ $\alpha$-GalCer-pulsed APC, in combination with intra-arterial infusion of $5 \times 10^{7}$ ex vivo-activated autologous type I NKT cells via tumor-feeding arteries $(255,256)$. Tumor regression and stable disease were reported in 10 of 10 of these patients (255). These clinical responses did, however, not correlate with the induction of immunological responses in blood (i.e., increase in type I NKT cell numbers and/or IFN- $\gamma$-producing type I NKT cells and NK cells). In addition, ex vivo-activated type I NKT cells were adoptively transferred to patients diagnosed with advanced or recurrent NSCL $\left(1 \times 10^{7}\right.$ or $5 \times 10^{7} / \mathrm{m}^{2}$ NKT cells per infusion) or advanced melanoma $\left(\sim 4 \times 10^{6}-\sim 2 \times 10^{8}\right.$ NKT cells per infusion) in phase I clinical trials $(253,254)$. Treatment was well tolerated and resulted in stable disease in 2 of 9 NSCL patients and 3 of 9 patients with advanced melanoma, respectively. However, the majority of patients developed progressive disease. This might be due to the fact that the numbers of administered ex vivo-activated autologous type I NKT cells were too low in comparison to the tumor load. Obtaining sufficient numbers of type I NKT cells might be a major challenge since type I NKT cell numbers are low in general, and especially in patients with cancer.

Recently, studies focused on increasing the specificity of NKT cells by transducing them with chimeric antigen receptors that are not HLA or CD1d restricted $(58,70,257)$. In addition, $\alpha$-GalCer/CD1d-antitumor fusion proteins were suggested as a treatment for cancer patients. For instance, $\alpha$-GalCer-loaded CD1d molecules fused with an antibody fragment specific for HER2 or CEA antigens induced potent antitumor activity in vitro and in vivo $(258,259)$. Recently, Horn et al. showed that CD3 $\times$ PD-L1 Bi-specific T cell engagers activated both $\mathrm{T}$ cells and NKT cells to kill PD-L1 ${ }^{+}$tumor cells in vitro (260). Another strategy that was suggested for the treatment of patients with solid tumors is vaccination with NKT-activating agents in combination with tumor antigens. For instance, a phase I study showed detectable NKT cell activity in patients with high-risk melanoma upon treatment with cancer/testis antigen-loaded DC in combination with $\alpha$-GalCer (261). However, in our opinion, increasing the specificity of NKT cells is not the most promising method of increasing the effectiveness of NKT-based immunotherapies. The strength of NKT cells does not rest in their cytotoxic capacities, but in their regulatory function. When the appropriate subsets are activated (i.e., $\mathrm{T}_{\mathrm{H}} 1$-like NKT cells), NKT cells might shift the tolerogenic and immunosuppressive state of both innate and adaptive cells toward antitumor activity. Therefore, instead of increasing the specificity of NKT cells, immunotherapies should focus on the most important function of NKT cells, their regulatory function.

In conclusion, several NKT cell-based immunotherapies have been tested in clinical trials. To date, a beneficial effect in a minority of cancer patients has been reported. These clinical trials were mainly based on the activation and expansion of type I NKT cells with $\alpha$-GalCer. As addressed in our hypothetical model (Figure 5), NKT cells may switch to immunosuppressive functional subsets or become anergic due to chronic stimulation during cancer progression which might explain the absence of beneficial clinical responses in patients upon treatment with $\alpha$-GalCer. We propose that it is essential to prevent and break NKT cell anergy in cancer patients and skew NKT cells in cancer patients toward $\mathrm{T}_{\mathrm{H}} 1$-like subsets with antitumor activity in addition to expansion of the NKT cell population.

\section{FOCUS OF FUTURE NKT CELL-BASED IMMUNOTHERAPIES}

In this review, we discussed the role of NKT cells in cancer and conclude that NKT cells play a central role in anticancer treatment due to their important regulatory function. To improve NKT cell-based immunotherapies for the treatment of cancer patients, several aspects of the current treatment strategies need further attention.

\section{Expansion of the NKT Cell Population}

$\mathrm{T}_{\mathrm{H}}$ 1-like NKT cells (either type I or type II) have the potential to induce effective antitumor responses. Combined with the fact that their numbers are decreased in cancer patients, it is essential to expand this cell population in patients. For instance, induced pluripotent stem cells might be used to expand the numbers of autologous NKT cells in patients ex vivo (262-264). Furthermore, culturing methods aiming at obtaining high numbers of NKT cells must be optimized. At the moment, according to the Clinical Trials registry, multiple clinical trials ${ }^{1}$ are ongoing that study the safety and clinical efficacy of adoptive type I NKT cell transfer in patients with solid tumors. As discussed in this review, this infusion should be accompanied by a protocol that prevents

${ }^{1}$ https://clinicaltrials.gov/ct2/show/NCT02562963, https://clinicaltrials.gov/ct2/ show/NCT03198923, and https://clinicaltrials.gov/ct2/show/NCT01801852. 
induction of NKT cell anergy and generation of immunosuppressive NKT cell subsets.

\section{Prevention and Breaking of NKT Cell Anergy}

Until now, only a limited number of studies focused on prevention or breaking of NKT cell anergy. Parekh et al. showed that blockade of the interaction between PD-1 and its ligands prevented the induction of type I NKT cell anergy in vivo (265). Blockade of the PD-1/PD-L1 axis was, however, unable to reverse established NKT cell anergy $(265,266)$. In addition, in vitro and in vivo studies showed that stimulation of type I NKT cells with IL-2 overcomes anergy and restores their capacity to proliferate $(144,146)$. The proliferative capacity of patient-derived type I NKT cells was also reported to increase upon COX-2 inhibition or culture with G-CSF $(222,267)$. It might, therefore, be an option to treat patients with a combination of anti-PD-1 antibody, such as nivolumab, combined with IL-2/G-CSF or COX-2 inhibition to prevent and reverse NKT cell anergy.

\section{Skewing of NKT Cells toward $T_{H}$ 1-Like Subsets}

NKT cells in which anergy was reversed retained their $\mathrm{T}_{\mathrm{H}} 2$-biased cytokine profile upon IL-2 stimulation and did not change back toward a $\mathrm{T}_{\mathrm{H}} 1$-like subset with antitumor activity (146). It is therefore also necessary to use agents that are able to skew the cytokine profile of activated NKT cells toward a $\mathrm{T}_{\mathrm{H}} 1$ profile, which means a change in functional subset. For instance, culturing of patientderived $\mathrm{T}_{\mathrm{H}} 2$-biased type I NKT cells with IL-12 resulted in IFN- $\gamma$ production of these cells in response to $\alpha$-GalCer in vitro (219). In addition, Laurent et al. showed that chemical modification of the $\alpha$-GalCer compound was able to increase $\mathrm{T}_{\mathrm{H}} 1$-associated cytokine production by activated type I NKT cells, whereas stimulation of type I NKT cells with conventional $\alpha$-GalCer resulted in production of both $\mathrm{T}_{\mathrm{H}} 1$ - and $\mathrm{T}_{\mathrm{H}} 2$-associated cytokines (268). Other synthetic agonists have also been described that induce a $\mathrm{T}_{\mathrm{H}} 1$-skewed cytokine profile in type I or type II NKT cells (83, 190, 269, 270). Hence, the use of modified NKT cell-activating agents in cancer patients might skew the cytokine profile of

\section{REFERENCES}

1. Parkin J, Cohen B. An overview of the immune system. Lancet (2001) 357(9270):1777-89. doi:10.1016/S0140-6736(00)04904-7

2. Lim WF, Inoue-Yokoo T, Tan KS, Lai MI, Sugiyama D. Hematopoietic cell differentiation from embryonic and induced pluripotent stem cells. Stem Cell Res Ther (2013) 4(3):71. doi:10.1186/scrt222

3. Haraguchi K, Takahashi T, Nakahara F, Matsumoto A, Kurokawa M, Ogawa S, et al. CD1d expression level in tumor cells is an important determinant for anti-tumor immunity by natural killer T cells. Leuk Lymphoma (2006) 47(10):2218-23. doi:10.1080/10428190600682688

4. Metelitsa LS, Naidenko OV, Kant A, Wu HW, Loza MJ, Perussia B, et al. Human NKT cells mediate antitumor cytotoxicity directly by recognizing target cell CD1d with bound ligand or indirectly by producing IL-2 to activate NK cells. J Immunol (2001) 167(6):3114-22. doi:10.4049/jimmunol.167.6.3114

5. Kuylenstierna C, Bjorkstrom NK, Andersson SK, Sahlstrom P, Bosnjak L, Paquin-Proulx D, et al. NKG2D performs two functions in invariant NKT cells: direct TCR-independent activation of NK-like cytolysis and co-stimulation
NKT cells toward a $T_{H} 1$ profile while simultaneously preventing the induction of anergy.

\section{CONCLUDING REMARKS}

Due to their important regulatory function, NKT cells are promising candidates for immunotherapies in patients diagnosed with cancer. However, NKT cell-based immunotherapies that focus on activating NKT cells have resulted in beneficial clinical responses in a minority of patients so far. In this review, we illustrated a hypothetical model regarding the role of NKT cells in solid tumors based on their function and phenotype. During early tumor development, $\mathrm{T}_{\mathrm{H}} 1$-like NKT cell subsets have the potential to initiate effective antitumor immune responses against tumors. However, when NKT cells become overstimulated and anergic during tumor progression, they lose their antitumor function and start facilitating immune escape. The role of NKT cells in cancer might therefore be more dynamic than initially thought. So far, studies have primarily focused on methods to activate and expand the type I NKT cell population in patients, but the contribution of functionally altered NKT cells to the failure of NKT cell-based immunotherapies has been largely ignored. In this review, we conclude that there should be three important focuses of future research in cancer patients: (1) expansion of the NKT cell population, (2) prevention and breaking of NKT cell anergy, and (3) skewing of NKT cells toward $\mathrm{T}_{\mathrm{H}} 1$-like subsets with antitumor activity.

\section{AUTHOR CONTRIBUTIONS}

DK compiled the literature sources, conceived of the presented idea, and wrote the manuscript. $\mathrm{PK}$ and $\mathrm{MH}$ contributed to scientific discussions and critically reviewed the manuscript.

\section{ACKNOWLEDGMENTS}

We thank Nikki Kromkamp (Communication in Science, Leiden University Medical Center) for proofreading and language editing.

of activation by CD1d. Eur J Immunol (2011) 41(7):1913-23. doi:10.1002/ eji.200940278

6. McEwen-Smith RM, Salio M, Cerundolo V. The regulatory role of invariant NKT cells in tumor immunity. Cancer Immunol Res (2015) 3(5):425-35. doi:10.1158/2326-6066.CIR-15-0062

7. Brennan PJ, Brigl M, Brenner MB. Invariant natural killer T cells: an innate activation scheme linked to diverse effector functions. Nat Rev Immunol (2013) 13(2):101-17. doi:10.1038/nri3369

8. Robertson FC, Berzofsky JA, Terabe M. NKT cell networks in the regulation of tumor immunity. Front Immunol (2014) 5:543. doi:10.3389/fimmu.2014.00543

9. Godfrey DI, Stankovic S, Baxter AG. Raising the NKT cell family. Nat Immunol (2010) 11(3):197-206. doi:10.1038/ni.1841

10. Kinjo Y, Illarionov P, Vela JL, Pei B, Girardi E, Li X, et al. Invariant natural killer $\mathrm{T}$ cells recognize glycolipids from pathogenic Gram-positive bacteria Nat Immunol (2011) 12(10):966-74. doi:10.1038/ni.2096

11. Zhou D, Mattner J, Cantu C III, Schrantz N, Yin N, Gao Y, et al. Lysosomal glycosphingolipid recognition by NKT cells. Science (2004) 306(5702):1786-9. doi:10.1126/science. 1103440 
12. Kumar V, Delovitch TL. Different subsets of natural killer T cells may vary in their roles in health and disease. Immunology (2014) 142(3):321-36. doi:10.1111/imm.12247

13. Porcelli S, Yockey CE, Brenner MB, Balk SP. Analysis of T cell antigen receptor (TCR) expression by human peripheral blood CD4-8- alpha/beta T cells demonstrates preferential use of several $\mathrm{V}$ beta genes and an invariant TCR alpha chain. J Exp Med (1993) 178(1):1-16. doi:10.1084/jem.178.1.1

14. Dellabona P, Casorati G, Friedli B, Angman L, Sallusto F, Tunnacliffe A, et al. In vivo persistence of expanded clones specific for bacterial antigens within the human T cell receptor alpha/beta CD4-8- subset. J Exp Med (1993) 177(6):1763-71. doi:10.1084/jem.177.6.1763

15. Dellabona P, Padovan E, Casorati G, Brockhaus M, Lanzavecchia A. An invariant V alpha 24-J alpha Q/V beta $11 \mathrm{~T}$ cell receptor is expressed in all individuals by clonally expanded CD4-8- T cells. J Exp Med (1994) 180(3): 1171-6. doi:10.1084/jem.180.3.1171

16. Lantz O, Bendelac A. An invariant $\mathrm{T}$ cell receptor alpha chain is used by a unique subset of major histocompatibility complex class I-specific CD4+ and CD4-8- T cells in mice and humans. J Exp Med (1994) 180(3):1097-106. doi:10.1084/jem.180.3.1097

17. Godfrey DI, MacDonald HR, Kronenberg M, Smyth MJ, Van Kaer L. NKT cells: what's in a name? Nat Rev Immunol (2004) 4(3):231-7. doi:10.1038/ nri1309

18. Terabe M, Berzofsky JA. The role of NKT cells in tumor immunity. Adv Cancer Res (2008) 101:277-348. doi:10.1016/S0065-230X(08)00408-9

19. Jahng A, Maricic I, Aguilera C, Cardell S, Halder RC, Kumar V. Prevention of autoimmunity by targeting a distinct, noninvariant CD1d-reactive T cell population reactive to sulfatide. J Exp Med (2004) 199(7):947-57. doi:10.1084/ jem.20031389

20. Bendelac A. Positive selection of mouse NK1+ T cells by CD1-expressing cortical thymocytes. J Exp Med (1995) 182(6):2091-6. doi:10.1084/jem.182. 6.2091

21. Coles MC, Raulet DH. NK1.1+ T cells in the liver arise in the thymus and are selected by interactions with class I molecules on CD4+CD8+ cells. J Immunol (2000) 164(5):2412-8. doi:10.4049/jimmunol.164.5.2412

22. Wei DG, Lee H, Park SH, Beaudoin L, Teyton L, Lehuen A, et al. Expansion and long-range differentiation of the NKT cell lineage in mice expressing CD1d exclusively on cortical thymocytes. J Exp Med (2005) 202(2):239-48. doi:10.1084/jem.20050413

23. Pellicci DG, Hammond KJ, Uldrich AP, Baxter AG, Smyth MJ, Godfrey DI. A natural killer T (NKT) cell developmental pathway involving a thymusdependent NK1.1(-)CD4(+) CD1d-dependent precursor stage. J Exp Med (2002) 195(7):835-44. doi:10.1084/jem.20011544

24. Gapin L, Matsuda JL, Surh CD, Kronenberg M. NKT cells derive from doublepositive thymocytes that are positively selected by CD1d. Nat Immunol (2001) 2(10):971-8. doi:10.1038/ni710

25. Sandberg JK, Stoddart CA, Brilot F, Jordan KA, Nixon DF. Development of innate CD4+ alpha-chain variable gene segment 24 (Valpha24) natural killer T cells in the early human fetal thymus is regulated by IL-7. Proc Natl Acad Sci U S A (2004) 101(18):7058-63. doi:10.1073/pnas.0305986101

26. Baev DV, Peng XH, Song L, Barnhart JR, Crooks GM, Weinberg KI, et al. Distinct homeostatic requirements of CD4+ and CD4- subsets of Valpha24invariant natural killer T cells in humans. Blood (2004) 104(13):4150-6. doi:10.1182/blood-2004-04-1629

27. Eger KA, Sundrud MS, Motsinger AA, Tseng M, Van Kaer L, Unutmaz D. Human natural killer $\mathrm{T}$ cells are heterogeneous in their capacity to reprogram their effector functions. PLoS One (2006) 1:e50. doi:10.1371/journal. pone. 0000050

28. Montoya CJ, Pollard D, Martinson J, Kumari K, Wasserfall C, Mulder CB, et al. Characterization of human invariant natural killer T subsets in health and disease using a novel invariant natural killer T cell-clonotypic monoclonal antibody, 6B11. Immunology (2007) 122(1):1-14. doi:10.1111/j.1365-2567.2007. 02647.x

29. Sandberg JK, Bhardwaj N, Nixon DF. Dominant effector memory characteristics, capacity for dynamic adaptive expansion, and sex bias in the innate Valpha24 NKT cell compartment. Eur JImmunol (2003) 33(3):588-96. doi:10.1002/eji.200323707

30. Lee PT, Benlagha K, Teyton L, Bendelac A. Distinct functional lineages of human V(alpha)24 natural killer T cells. J Exp Med (2002) 195(5):637-41. doi:10.1084/jem.20011908
31. Chan WK, Rujkijyanont P, Neale G, Yang J, Bari R, Das Gupta N, et al. Multiplex and genome-wide analyses reveal distinctive properties of KIR+ and CD56+ T cells in human blood. J Immunol (2013) 191(4):1625-36. doi:10.4049/jimmunol.1300111

32. Bandyopadhyay K, Marrero I, Kumar V. NKT cell subsets as key participants in liver physiology and pathology. Cell Mol Immunol (2016) 13(3):337-46. doi: $10.1038 / \mathrm{cmi} .2015 .115$

33. Berzins SP, Smyth MJ, Baxter AG. Presumed guilty: natural killer T cell defects and human disease. Nat Rev Immunol (2011) 11(2):131-42. doi:10.1038/ nri2904

34. Matangkasombut P, Marigowda G, Ervine A, Idris L, Pichavant M, Kim HY, et al. Natural killer T cells in the lungs of patients with asthma. J Allergy Clin Immunol (2009) 123(5):1181-5. doi:10.1016/j.jaci.2009.02.013

35. Kenna T, Golden-Mason L, Porcelli SA, Koezuka Y, Hegarty JE, O’Farrelly C, et al. NKT cells from normal and tumor-bearing human livers are phenotypically and functionally distinct from murine NKT cells. J Immunol (2003) 171(4):1775-9. doi:10.4049/jimmunol.171.10.5631

36. Wingender G, Kronenberg M. Role of NKT cells in the digestive system. IV. The role of canonical natural killer $\mathrm{T}$ cells in mucosal immunity and inflammation. Am J Physiol Gastrointest Liver Physiol (2008) 294(1):G1-8. doi:10.1152/ajpgi.00437.2007

37. Galante NZ, Ozaki KS, Cenedeze MA, Kallas EG, Salomao R, Pacheco-Silva A, et al. Frequency of Valpha24+Vbeta11+ NKT cells in peripheral blood of human kidney transplantation recipients. Int Immunopharmacol (2005) 5(1):53-8. doi:10.1016/j.intimp.2004.09.013

38. Lynch L, O'Shea D, Winter DC, Geoghegan J, Doherty DG, O'Farrelly C. Invariant NKT cells and CD1d(+) cells amass in human omentum and are depleted in patients with cancer and obesity. Eur J Immunol (2009) 39(7): 1893-901. doi:10.1002/eji.200939349

39. Chan AC, Serwecinska L, Cochrane A, Harrison LC, Godfrey DI, Berzins SP. Immune characterization of an individual with an exceptionally high natural killer T cell frequency and her immediate family. Clin Exp Immunol (2009) 156(2):238-45. doi:10.1111/j.1365-2249.2009.03888.x

40. Woo SY, Jung YJ, Ryu KH, Park HY, Kie JH, Im SA, et al. In vitro differentiation of natural killer $\mathrm{T}$ cells from human cord blood CD34+ cells. Br J Haematol (2003) 121(1):148-56. doi:10.1046/j.1365-2141.2003.04230.x

41. Gao B, Radaeva S, Park O. Liver natural killer and natural killer T cells: immunobiology and emerging roles in liver diseases. JLeukoc Biol (2009) 86(3):513-28. doi:10.1189/JLB.0309135

42. Timonen T, Ortaldo JR, Herberman RB. Characteristics of human large granular lymphocytes and relationship to natural killer and K cells. J Exp Med (1981) 153(3):569-82. doi:10.1084/jem.153.3.569

43. Nakatani K, Kaneda K, Seki S, Nakajima Y. Pit cells as liver-associated natural killer cells: morphology and function. Med Electron Microsc (2004) 37(1):29-36. doi:10.1007/s00795-003-0229-9

44. Daibata M, Matsuo Y, Machida H, Taguchi T, Ohtsuki Y, Taguchi H. Differential gene-expression profiling in the leukemia cell lines derived from indolent and aggressive phases of CD56+ T-cell large granular lymphocyte leukemia. Int J Cancer (2004) 108(6):845-51. doi:10.1002/ijc.11647

45. van der Vliet HJ, Pinedo HM, von Blomberg BM, van den Eertwegh AJ, Scheper RJ, Giaccone G. Natural killer T cells. Lancet Oncol (2002) 3(9):574. doi:10.1016/S1470-2045(02)00850-1

46. Gumperz JE, Miyake S, Yamamura T, Brenner MB. Functionally distinct subsets of CD1d-restricted natural killer T cells revealed by CD1d tetramer staining. J Exp Med (2002) 195(5):625-36. doi:10.1084/jem.20011786

47. Hammond KJ, Poulton LD, Palmisano LJ, Silveira PA, Godfrey DI, Baxter AG. alpha/beta-T cell receptor (TCR)+CD4-CD8- (NKT) thymocytes prevent insulin-dependent diabetes mellitus in nonobese diabetic (NOD)/Lt mice by the influence of interleukin (IL)-4 and/or IL-10. JExp Med (1998) 187(7):1047-56. doi:10.1084/jem.187.7.1047

48. Lehuen A, Lantz O, Beaudoin L, Laloux V, Carnaud C, Bendelac A, et al Overexpression of natural killer $\mathrm{T}$ cells protects Valpha14- Jalpha281 transgenic nonobese diabetic mice against diabetes. JExp Med (1998) 188(10):1831-9. doi:10.1084/jem.188.10.1831

49. Terabe M, Matsui S, Noben-Trauth N, Chen H, Watson C, Donaldson DD, et al. NKT cell-mediated repression of tumor immunosurveillance by IL-13 and the IL-4R-STAT6 pathway. Nat Immunol (2000) 1(6):515-20. doi:10.1038/82771

50. Moreira-Teixeira L, Resende M, Coffre M, Devergne O, Herbeuval JP, Hermine O, et al. Proinflammatory environment dictates the IL-17-producing 
capacity of human invariant NKT cells. J Immunol (2011) 186(10):5758-65. doi:10.4049/jimmunol.1003043

51. Snyder-Cappione JE, Tincati C, Eccles-James IG, Cappione AJ, Ndhlovu LC, Koth LL, et al. A comprehensive ex vivo functional analysis of human NKT cells reveals production of MIP1-alpha and MIP1-beta, a lack of IL-17, and a Th1-bias in males. PLoS One (2010) 5(11):e15412. doi:10.1371/journal. pone. 0015412

52. Moreira-Teixeira L, Resende M, Devergne O, Herbeuval JP, Hermine O, Schneider E, et al. Rapamycin combined with TGF-beta converts human invariant NKT cells into suppressive Foxp3+ regulatory cells. J Immunol (2012) 188(2):624-31. doi:10.4049/jimmunol.1102281

53. Chang PP, Barral P, Fitch J, Pratama A, Ma CS, Kallies A, et al. Identification of Bcl-6-dependent follicular helper NKT cells that provide cognate help for B cell responses. Nat Immunol (2012) 13(1):35-43. doi:10.1038/ni.2166

54. Gapin L. Development of invariant natural killer T cells. Curr Opin Immunol (2016) 39:68-74. doi:10.1016/j.coi.2016.01.001

55. Sullivan BA, Nagarajan NA, Wingender G, Wang J, Scott I, Tsuji M, et al. Mechanisms for glycolipid antigen-driven cytokine polarization by Valpha14i NKT cells. J Immunol (2010) 184(1):141-53. doi:10.4049/jimmunol.0902880

56. DuPage M, Bluestone JA. Harnessing the plasticity of $\mathrm{CD} 4(+) \mathrm{T}$ cells to treat immune-mediated disease. Nat Rev Immunol (2016) 16(3):149-63. doi:10.1038/nri.2015.18

57. van der Vliet HJ, Wang R, Yue SC, Koon HB, Balk SP, Exley MA. Circulating myeloid dendritic cells of advanced cancer patients result in reduced activation and a biased cytokine profile in invariant NKT cells. J Immunol (2008) 180(11):7287-93. doi:10.4049/jimmunol.180.11.7287

58. Heczey A, Liu D, Tian G, Courtney AN, Wei J, Marinova E, et al. Invariant NKT cells with chimeric antigen receptor provide a novel platform for safe and effective cancer immunotherapy. Blood (2014) 124(18):2824-33. doi:10.1182/ blood-2013-11-541235

59. Metelitsa LS. Flow cytometry for natural killer T cells: multi-parameter methods for multifunctional cells. Clin Immunol (2004) 110(3):267-76. doi:10.1016/j.clim.2003.11.005

60. Porcelli S, Gerdes D, Fertig AM, Balk SP. Human T cells expressing an invariant V alpha 24-J alpha Q TCR alpha are CD4- and heterogeneous with respect to TCR beta expression. Hum Immunol (1996) 48(1-2):63-7. doi:10.1016/0198-8859(96)00090-0

61. Exley M, Garcia J, Balk SP, Porcelli S. Requirements for CD1d recognition by human invariant Valpha24+ CD4-CD8- T cells. JExp Med (1997) 186(1):109-20. doi:10.1084/jem.186.1.109

62. KentSC, Hafler DA, Strominger JL, Wilson SB. Noncanonical Valpha24JalphaQ $\mathrm{T}$ cells with conservative alpha chain CDR3 region amino acid substitutions are restricted by CD1d. Hum Immunol (1999) 60(11):1080-9. doi:10.1016/ S0198-8859(99)00109-3

63. Lee PT, Putnam A, Benlagha K, Teyton L, Gottlieb PA, Bendelac A. Testing the NKT cell hypothesis of human IDDM pathogenesis. JClin Invest (2002) 110(6):793-800. doi:10.1172/JCI0215832

64. Schumann J, Voyle RB, Wei BY, MacDonald HR. Cutting edge: influence of the TCR V beta domain on the avidity of CD1d:alpha-galactosylceramide binding by invariant $\mathrm{V}$ alpha 14 NKT cells. J Immunol (2003) 170(12):5815-9. doi:10.4049/jimmunol.170.12.5815

65. Benlagha K, Weiss A, Beavis A, Teyton L, Bendelac A. In vivo identification of glycolipid antigen-specific T cells using fluorescent CD1d tetramers. J Exp Med (2000) 191(11):1895-903. doi:10.1084/jem.191.11.1895

66. Matsuda JL, Naidenko OV, Gapin L, Nakayama T, Taniguchi M, Wang CR, et al. Tracking the response of natural killer T cells to a glycolipid antigen using CD1d tetramers. J Exp Med (2000) 192(5):741-54. doi:10.1084/jem.192.5.741

67. Sidobre S, Kronenberg M. CD1 tetramers: a powerful tool for the analysis of glycolipid-reactive T cells. J Immunol Methods (2002) 268(1):107-21. doi:10.1016/S0022-1759(02)00204-1

68. Sag D, Ozkan M, Kronenberg M, Wingender G. Improved detection of cytokines produced by invariant NKT cells. Sci Rep (2017) 7(1):16607. doi:10.1038/s41598-017-16832-1

69. van Der Vliet HJ, Nishi N, de Gruijl TD, von Blomberg BM, van den Eertwegh AJ, Pinedo HM, et al. Human natural killer T cells acquire a memory-activated phenotype before birth. Blood (2000) 95(7):2440-2.

70. Tian G, Courtney AN, Jena B, Heczey A, Liu D, Marinova E, et al. CD62L+ NKT cells have prolonged persistence and antitumor activity in vivo. J Clin Invest (2016) 126(6):2341-55. doi:10.1172/JCI83476
71. Kitayama S, Zhang R, Liu TY, Ueda N, Iriguchi S, Yasui Y, et al. Cellular adjuvant properties, direct cytotoxicity of re-differentiated Valpha24 invariant NKT-like cells from human induced pluripotent stem cells. Stem Cell Reports (2016) 6(2):213-27. doi:10.1016/j.stemcr.2016.01.005

72. Hintzen RQ, de Jong R, Lens SM, Brouwer M, Baars P, van Lier RA. Regulation of CD27 expression on subsets of mature T-lymphocytes. J Immunol (1993) 151(5):2426-35.

73. Hendriks J, Gravestein LA, Tesselaar K, van Lier RA, Schumacher TN, Borst J. $\mathrm{CD} 27$ is required for generation and long-term maintenance of $\mathrm{T}$ cell immunity. Nat Immunol (2000) 1(5):433-40. doi:10.1038/80877

74. Kim S, Lalani S, Parekh VV, Vincent TL, Wu L, Van Kaer L. Impact of bacteria on the phenotype, functions, and therapeutic activities of invariant NKT cells in mice. J Clin Invest (2008) 118(6):2301-15. doi:10.1172/JCI33071

75. Hudspeth K, Silva-Santos B, Mavilio D. Natural cytotoxicity receptors: broader expression patterns and functions in innate and adaptive immune cells. Front Immunol (2013) 4:69. doi:10.3389/fimmu.2013.00069

76. Harada M, Seino K, Wakao H, Sakata S, Ishizuka Y, Ito T, et al. Down-regulation of the invariant Valpha14 antigen receptor in NKT cells upon activation. Int Immunol (2004) 16(2):241-7. doi:10.1093/intimm/dxh023

77. Ikarashi Y, Iizuka A, Koshidaka Y, Heike Y, Takaue Y, Yoshida M, et al. Phenotypical and functional alterations during the expansion phase of invariant Valpha14 natural killer T (Valpha14i NKT) cells in mice primed with alpha-galactosylceramide. Immunology (2005) 116(1):30-7. doi:10.1111/j.1365-2567.2005.02193.x

78. Baginska J, Viry E, Paggetti J, Medves S, Berchem G, Moussay E, et al. The critical role of the tumor microenvironment in shaping natural killer cellmediated anti-tumor immunity. Front Immunol (2013) 4:490. doi:10.3389/ fimmu.2013.00490

79. Kim $\mathrm{CH}$, Johnston B, Butcher EC. Trafficking machinery of NKT cells: shared and differential chemokine receptor expression among $\mathrm{V}$ alpha $24(+)$ $\mathrm{V}$ beta 11(+) NKT cell subsets with distinct cytokine-producing capacity. Blood (2002) 100(1):11-6. doi:10.1182/blood-2001-12-0196

80. Thomas SY, Hou R, Boyson JE, Means TK, Hess C, Olson DP, et al. CD1drestricted NKT cells express a chemokine receptor profile indicative of Th1-type inflammatory homing cells. JImmunol (2003) 171(5):2571-80. doi:10.4049/jimmunol.171.5.2571

81. Campbell JJ, Qin S, Unutmaz D, Soler D, Murphy KE, Hodge MR, et al. Unique subpopulations of CD56+ NK and NK-T peripheral blood lymphocytes identified by chemokine receptor expression repertoire. J Immunol (2001) 166(11):6477-82. doi:10.4049/jimmunol.166.11.6477

82. Liu D, Song L, Brawley VS, Robison N, Wei J, Gao X, et al. Medulloblastoma expresses CD1d and can be targeted for immunotherapy with NKT cells. Clin Immunol (2013) 149(1):55-64. doi:10.1016/j.clim.2013.06.005

83. Zhao J, Weng X, Bagchi S, Wang CR. Polyclonal type II natural killer T cells require PLZF and SAP for their development and contribute to CpGmediated antitumor response. Proc Natl Acad Sci U S A (2014) 111(7):2674-9. doi:10.1073/pnas.1323845111

84. Fuss IJ, Joshi B, Yang Z, Degheidy H, Fichtner-Feigl S, de Souza H, et al. IL-13Ralpha2-bearing, type II NKT cells reactive to sulfatide self-antigen populate the mucosa of ulcerative colitis. Gut (2014) 63(11):1728-36. doi:10.1136/ gutjnl-2013-305671

85. Marrero I, Ware R, Kumar V. Type II NKT cells in inflammation, autoimmunity, microbial immunity, and cancer. Front Immunol (2015) 6:316. doi:10.3389/fimmu.2015.00316

86. Terabe M, Swann J, Ambrosino E, Sinha P, Takaku S, Hayakawa Y, et al. A nonclassical non-Valpha14Jalpha18 CD1d-restricted (type II) NKT cell is sufficient for down-regulation of tumor immunosurveillance. JExp Med (2005) 202(12):1627-33. doi:10.1084/jem.20051381

87. Renukaradhya GJ, Khan MA, Vieira M, Du W, Gervay-Hague J, Brutkiewicz RR. Type I NKT cells protect (and type II NKT cells suppress) the host's innate antitumor immune response to a B-cell lymphoma. Blood (2008) 111(12): 5637-45. doi:10.1182/blood-2007-05-092866

88. Terabe M, Berzofsky JA. The immunoregulatory role of type I and type II NKT cells in cancer and other diseases. Cancer Immunol Immunother (2014) 63(3):199-213. doi:10.1007/s00262-013-1509-4

89. Arrenberg P, Halder R, Dai Y, Maricic I, Kumar V. Oligoclonality and innatelike features in the TCR repertoire of type II NKT cells reactive to a betalinked self-glycolipid. Proc Natl Acad Sci U S A (2010) 107(24):10984-9. doi:10.1073/pnas.1000576107 
90. Parish S, Izhak L, Xia Z, Suzuki M, Terabe M, Berzofsky J. Identification of sulfatide reactive type II NKT cells using CD1d dimers. [abstract]. In: Proceedings of the 104th Annual Meeting of the American Association for Cancer Research. Washington, DC; Philadelphia, PA: AACR; Cancer Res (2013) 73(8 Suppl):Abstract no 1262. doi:10.1158/1538-7445.AM2013-1262

91. Peng LS, Mao FY, Zhao YL, Wang TT, Chen N, Zhang JY, et al. Altered phenotypic and functional characteristics of CD3+CD56+ NKT-like cells in human gastric cancer. Oncotarget (2016) 7(34):55222-30. doi:10.18632/ oncotarget.10484

92. Li XF, Dai D, Song XY, Liu JJ, Zhu L, Zhu X, et al. A different representation of natural $\mathrm{T}$ cells and natural killer cells between tumor-infiltrating and periphery lymphocytes in human hepatocellular carcinoma. Oncol Lett (2017) 13(5):3291-8. doi:10.3892/ol.2017.5808

93. van den Heuvel MJ, Peralta CG, Hatta K, Han VK, Clark DA. Decline in number of elevated blood CD3(+) CD56(+) NKT cells in response to intravenous immunoglobulin treatment correlates with successful pregnancy. Am J Reprod Immunol (2007) 58(5):447-59. doi:10.1111/j.1600-0897.2007.00529.x

94. Jiang Y, Cui X, Cui C, Zhang J, Zhou F, Zhang Z, et al. The function of CD3+CD56+ NKT-like cells in HIV-infected individuals. Biomed Res Int (2014) 2014:863625. doi:10.1155/2014/863625

95. Bai Y, Zhang Y, Yang Q, Hou Y, Hu N, Wang D, et al. The aberrant expression of stimulatory and inhibitory killer immunoglobulin-like receptors in NK- and NKT-cells contributes to lupus. Clin Lab (2014) 60(5):717-27. doi:10.7754/Clin.Lab.2013.130435

96. Mingari MC, Schiavetti F, Ponte M, Vitale C, Maggi E, Romagnani S, et al. Human CD8+ T lymphocyte subsets that express HLA class I-specific inhibitory receptors represent oligoclonally or monoclonally expanded cell populations. Proc Natl Acad Sci U S A (1996) 93(22):12433-8. doi:10.1073/ pnas.93.22.12433

97. Bendelac A, Lantz O, Quimby ME, Yewdell JW, Bennink JR, Brutkiewicz RR. CD1 recognition by mouse NK1+ T lymphocytes. Science (1995) 268(5212): 863-5. doi:10.1126/science.7538697

98. Blumberg RS, Terhorst C, Bleicher P, McDermott FV, Allan CH, Landau SB, et al. Expression of a nonpolymorphic MHC class I-like molecule, CD1D, by human intestinal epithelial cells. J Immunol (1991) 147(8):2518-24.

99. Canchis PW, Bhan AK, Landau SB, Yang L, Balk SP, Blumberg RS. Tissue distribution of the non-polymorphic major histocompatibility complex class I-like molecule, CD1d. Immunology (1993) 80(4):561-5.

100. Bendelac A, Savage PB, Teyton L. The biology of NKT cells. Annu Rev Immunol (2007) 25:297-336. doi:10.1146/annurev.immunol.25.022106.141711

101. Barral DC, Brenner MB. CD1 antigen presentation: how it works. Nat Rev Immunol (2007) 7(12):929-41. doi:10.1038/nri2191

102. Jayawardena-Wolf J, Benlagha K, Chiu YH, Mehr R, Bendelac A. CD1d endosomal trafficking is independently regulated by an intrinsic CD1d-encoded tyrosine motif and by the invariant chain. Immunity (2001) 15(6):897-908. doi:10.1016/S1074-7613(01)00240-0

103. Salio M, Ghadbane H, Dushek O, Shepherd D, Cypen J, Gileadi U, et al. Saposins modulate human invariant natural killer $\mathrm{T}$ cells self-reactivity and facilitate lipid exchange with CD1d molecules during antigen presentation. Proc Natl Acad Sci U S A (2013) 110(49):E4753-61. doi:10.1073/ pnas. 1310050110

104. Selvanantham T, Escalante NK, Cruz Tleugabulova M, Fieve S, Girardin SE, Philpott DJ, et al. Nod1 and Nod2 enhance TLR-mediated invariant NKT cell activation during bacterial infection. J Immunol (2013) 191(11):5646-54. doi:10.4049/jimmunol.1301412

105. De Santo C, Arscott R, Booth S, Karydis I, Jones M, Asher R, et al. Invariant NKT cells modulate the suppressive activity of IL-10-secreting neutrophils differentiated with serum amyloid A. Nat Immunol (2010) 11(11):1039-46. doi:10.1038/ni.1942

106. Brigl M, Bry L, Kent SC, Gumperz JE, Brenner MB. Mechanism of CD1drestricted natural killer $\mathrm{T}$ cell activation during microbial infection. Nat Immunol (2003) 4(12):1230-7. doi:10.1038/ni1002

107. Kinjo Y, Tupin E, Wu D, Fujio M, Garcia-Navarro R, Benhnia MR, et al. Natural killer $\mathrm{T}$ cells recognize diacylglycerol antigens from pathogenic bacteria. Nat Immunol (2006) 7(9):978-86. doi:10.1038/ni1380

108. Fischer K, Scotet E, Niemeyer M, Koebernick H, Zerrahn J, Maillet S, et al. Mycobacterial phosphatidylinositol mannoside is a natural antigen for CD1d-restricted T cells. Proc Natl Acad Sci U S A (2004) 101(29):10685-90. doi:10.1073/pnas.0403787101
109. Kinjo Y, Wu D, Kim G, Xing GW, Poles MA, Ho DD, et al. Recognition of bacterial glycosphingolipids by natural killer T cells. Nature (2005) 434(7032):520-5. doi:10.1038/nature03407

110. Mattner J, Debord KL, Ismail N, Goff RD, Cantu CIII, Zhou D, et al. Exogenous and endogenous glycolipid antigens activate NKT cells during microbial infections. Nature (2005) 434(7032):525-9. doi:10.1038/nature03408

111. Sriram V, Du W, Gervay-Hague J, Brutkiewicz RR. Cell wall glycosphingolipids of Sphingomonas paucimobilis are CD1d-specific ligands for NKT cells. Eur J Immunol (2005) 35(6):1692-701. doi:10.1002/eji.200526157

112. Brennan PJ, Tatituri RV, Brigl M, Kim EY, Tuli A, Sanderson JP, et al. Invariant natural killer $\mathrm{T}$ cells recognize lipid self antigen induced by microbial danger signals. Nat Immunol (2011) 12(12):1202-11. doi:10.1038/ni.2143

113. Chang DH, Deng H, Matthews P, Krasovsky J, Ragupathi G, Spisek R, et al. Inflammation-associated lysophospholipids as ligands for CD1d-restricted T cells in human cancer. Blood (2008) 112(4):1308-16. doi:10.1182/ blood-2008-04-149831

114. Tatituri RV, Watts GF, Bhowruth V, Barton N, Rothchild A, Hsu FF, et al. Recognition of microbial and mammalian phospholipid antigens by NKT cells with diverse TCRs. Proc Natl Acad Sci U S A (2013) 110(5):1827-32. doi:10.1073/ pnas. 1220601110

115. Wingender G, Krebs P, Beutler B, Kronenberg M. Antigen-specific cytotoxicity by invariant NKT cells in vivo is CD95/CD178-dependent and is correlated with antigenic potency. J Immunol (2010) 185(5):2721-9. doi:10.4049/ jimmunol.1001018

116. Crowe NY, Uldrich AP, Kyparissoudis K, Hammond KJ, Hayakawa Y, Sidobre S, et al. Glycolipid antigen drives rapid expansion and sustained cytokine production by NK T cells. J Immunol (2003) 171(8):4020-7. doi:10.4049/ jimmunol.171.8.4020

117. Nagaleekar VK, Sabio G, Aktan I, Chant A, Howe IW, Thornton TM, et al. Translational control of NKT cell cytokine production by $\mathrm{p} 38$ MAPK. J Immunol (2011) 186(7):4140-6. doi:10.4049/jimmunol.1002614

118. Coquet JM, Chakravarti S, Kyparissoudis K, McNab FW, Pitt LA, McKenzie BS, et al. Diverse cytokine production by NKT cell subsets and identification of an IL-17-producing CD4-NK1.1- NKT cell population. Proc Natl Acad Sci U S A (2008) 105(32):11287-92. doi:10.1073/pnas.0801631105

119. Nakagawa R, Nagafune I, Tazunoki Y, Ehara H, Tomura H, Iijima R, et al. Mechanisms of the antimetastatic effect in the liver and of the hepatocyte injury induced by alpha-galactosylceramide in mice. JImmunol (2001) 166(11):6578-84. doi:10.4049/jimmunol.166.11.6578

120. Bernin H, Fehling H, Marggraff C, Tannich E, Lotter H. The cytokine profile of human NKT cells and PBMCs is dependent on donor sex and stimulus. Med Microbiol Immunol (2016) 205(4):321-32. doi:10.1007/s00430-0160449-y

121. Long EO, Kim HS, Liu D, Peterson ME, Rajagopalan S. Controlling natural killer cell responses: integration of signals for activation and inhibition. AnnuRevImmunol(2013)31:227-58.doi:10.1146/annurev-immunol-020711075005

122. Pegram HJ, Andrews DM, Smyth MJ, Darcy PK, Kershaw MH. Activating and inhibitory receptors of natural killer cells. Immunol Cell Biol (2011) 89(2):216-24. doi:10.1038/icb.2010.78

123. Gonzalez S, Lopez-Soto A, Suarez-Alvarez B, Lopez-Vazquez A, LopezLarrea C. NKG2D ligands: key targets of the immune response. Trends Immunol (2008) 29(8):397-403. doi:10.1016/j.it.2008.04.007

124. Bottino C, Castriconi R, Pende D, Rivera P, Nanni M, Carnemolla B, et al. Identification of PVR (CD155) and Nectin-2 (CD112) as cell surface ligands for the human DNAM-1 (CD226) activating molecule. J Exp Med (2003) 198(4):557-67. doi:10.1084/jem.20030788

125. Moretta A, Pende D, Locatelli F, Moretta L. Activating and inhibitory killer immunoglobulin-like receptors (KIR) in haploidentical haemopoietic stem cell transplantation to cure high-risk leukaemias. Clin Exp Immunol (2009) 157(3):325-31. doi:10.1111/j.1365-2249.2009.03983.x

126. Mandelboim O, Davis DM, Reyburn HT, Vales-Gomez M, Sheu EG, Pazmany L, et al. Enhancement of class II-restricted T cell responses by costimulatory NK receptors for class I MHC proteins. Science (1996) 274(5295):2097-100. doi:10.1126/science.274.5295.2097

127. Mandelboim O, Kent S, Davis DM, Wilson SB, Okazaki T, Jackson R, et al. Natural killer activating receptors trigger interferon gamma secretion from T cells and natural killer cells. Proc Natl Acad Sci US A (1998) 95(7):3798-803. doi:10.1073/pnas.95.7.3798 
128. Martin MP, Gao X, Lee JH, Nelson GW, Detels R, Goedert JJ, et al. Epistatic interaction between KIR3DS1 and HLA-B delays the progression to AIDS. Nat Genet (2002) 31(4):429-34. doi:10.1038/ng934

129. Vilches C, Parham P. KIR: diverse, rapidly evolving receptors of innate and adaptive immunity. Annu Rev Immunol (2002) 20:217-51. doi:10.1146/ annurev.immunol.20.092501.134942

130. Guerra N, Michel F, Gati A, Gaudin C, Mishal Z, Escudier B, et al. Engagement of the inhibitory receptor CD158a interrupts TCR signaling, preventing dynamic membrane reorganization in CTL/tumor cell interaction. Blood (2002) 100(8):2874-81. doi:10.1182/blood-2002-02-0643

131. De Maria A, Ferraris A, Guastella M, Pilia S, Cantoni C, Polero L, et al. Expression of HLA class I-specific inhibitory natural killer cell receptors in HIV-specific cytolytic T lymphocytes: impairment of specific cytolytic functions. Proc Natl Acad Sci U S A (1997) 94(19):10285-8. doi:10.1073/ pnas.94.19.10285

132. D'Andrea A, Chang C, Phillips JH, Lanier LL. Regulation of T cell lymphokine production by killer cell inhibitory receptor recognition of self HLA class I alleles. J Exp Med (1996) 184(2):789-94. doi:10.1084/jem.184.2.789

133. Phillips JH, Gumperz JE, Parham P, Lanier LL. Superantigen-dependent, cell-mediated cytotoxicity inhibited by MHC class I receptors on T lymphocytes. Science (1995) 268(5209):403-5. doi:10.1126/science.7716542

134. Kawamura T, Takeda K, Kaneda H, Matsumoto H, Hayakawa Y, Raulet DH, et al. NKG2A inhibits invariant NKT cell activation in hepatic injury. J Immunol (2009) 182(1):250-8. doi:10.4049/jimmunol.182.1.250

135. Dutertre CA, Bonnin-Gelize E, Pulford K, Bourel D, Fridman WH, Teillaud JL. A novel subset of NK cells expressing high levels of inhibitory FcgammaRIIB modulating antibody-dependent function. J Leukoc Biol (2008) 84(6):1511-20. doi:10.1189/jlb.0608343

136. Nagarajan NA, Kronenberg M. Invariant NKT cells amplify the innate immune response to lipopolysaccharide. J Immunol (2007) 178(5):2706-13. doi:10.4049/jimmunol.178.5.2706

137. Leite-De-Moraes MC, Hameg A, Arnould A, Machavoine F, Koezuka Y, Schneider E, et al. A distinct IL-18-induced pathway to fully activate NK $\mathrm{T}$ lymphocytes independently from TCR engagement. JImmunol (1999) 163(11):5871-6.

138. Fehniger TA, Shah MH, Turner MJ, VanDeusen JB, Whitman SP, Cooper MA, et al. Differential cytokine and chemokine gene expression by human NK cells following activation with IL-18 or IL-15 in combination with IL-12: implications for the innate immune response. J Immunol (1999) 162(8): 4511-20.

139. Fujii S, Shimizu K, Smith C, Bonifaz L, Steinman RM. Activation of natural killer $\mathrm{T}$ cells by alpha-galactosylceramide rapidly induces the full maturation of dendritic cells in vivo and thereby acts as an adjuvant for combined CD4 and CD8 T cell immunity to a coadministered protein. J Exp Med (2003) 198(2):267-79. doi:10.1084/jem.20030324

140. Fujii S, Liu K, Smith C, Bonito AJ, Steinman RM. The linkage of innate to adaptive immunity via maturing dendritic cells in vivo requires CD40 ligation in addition to antigen presentation and CD80/86 costimulation. J Exp Med (2004) 199(12):1607-18. doi:10.1084/jem.20040317

141. Okamura H, Tsutsi H, Komatsu T, Yutsudo M, Hakura A, Tanimoto T, et al. Cloning of a new cytokine that induces IFN-gamma production by $\mathrm{T}$ cells. Nature (1995) 378(6552):88-91. doi:10.1038/378088a0

142. Bonish B, Jullien D, Dutronc Y, Huang BB, Modlin R, Spada FM, et al. Overexpression of CD1d by keratinocytes in psoriasis and CD1d-dependent IFN-gamma production by NK-T cells. J Immunol (2000) 165(7):4076-85. doi:10.4049/jimmunol.165.7.4076

143. Singh AK, Gaur P, Das SN. Natural killer T cell anergy, co-stimulatory molecules and immunotherapeutic interventions. Hum Immunol (2014) 75(3):250-60. doi:10.1016/j.humimm.2013.12.004

144. Parekh VV, Wilson MT, Olivares-Villagomez D, Singh AK, Wu L, Wang CR, et al. Glycolipid antigen induces long-term natural killer $\mathrm{T}$ cell anergy in mice. J Clin Invest (2005) 115(9):2572-83. doi:10.1172/JCI24762

145. Sullivan BA, Kronenberg M. Activation or anergy: NKT cells are stunned by alpha-galactosylceramide. J Clin Invest (2005) 115(9):2328-9. doi:10.1172/ JCI26297

146. Iyoda T, Ushida M, Kimura Y, Minamino K, Hayuka A, Yokohata S, et al. Invariant NKT cell anergy is induced by a strong TCR-mediated signal plus co-stimulation. Int Immunol (2010) 22(11):905-13. doi:10.1093/intimm/ dxq444
147. Sidobre S, Hammond KJ, Benazet-Sidobre L, Maltsev SD, Richardson SK, Ndonye RM, et al. The $\mathrm{T}$ cell antigen receptor expressed by Valpha14i NKT cells has a unique mode of glycosphingolipid antigen recognition. Proc Natl Acad Sci U S A (2004) 101(33):12254-9. doi:10.1073/pnas.0404632101

148. Kuklina EM. Molecular mechanisms of T-cell anergy. Biochemistry (Mosc) (2013) 78(2):144-56. doi:10.1134/S000629791302003X

149. Crespo J, Sun H, Welling TH, Tian Z, Zou W. T cell anergy, exhaustion, senescence, and stemness in the tumor microenvironment. Curr Opin Immunol (2013) 25(2):214-21. doi:10.1016/j.coi.2012.12.003

150. Parekh VV, Lalani S, Van Kaer L. The in vivo response of invariant natural killer T cells to glycolipid antigens. Int Rev Immunol (2007) 26(1-2):31-48. doi:10.1080/08830180601070179

151. Leite-de-Moraes MC, Herbelin A, Gouarin C, Koezuka Y, Schneider E, Dy M. Fas/Fas ligand interactions promote activation-induced cell death of NK T lymphocytes. J Immunol (2000) 165(8):4367-71. doi:10.4049/jimmunol. 165.8.4367

152. Yang JQ, Saxena V, Xu H, Van Kaer L, Wang CR, Singh RR. Repeated alpha-galactosylceramide administration results in expansion of NK T cells and alleviates inflammatory dermatitis in MRL-lpr/lpr mice. J Immunol (2003) 171(8):4439-46. doi:10.4049/jimmunol.171.8.4439

153. Sag D, Krause P, Hedrick CC, Kronenberg M, Wingender G. IL-10-producing NKT10 cells are a distinct regulatory invariant NKT cell subset. J Clin Invest (2014) 124(9):3725-40. doi:10.1172/JCI72308

154. Maldonado RA, von Andrian UH. How tolerogenic dendritic cells induce regulatory T cells. Adv Immunol (2010) 108:111-65. doi:10.1016/B978-0-12380995-7.00004-5

155. Mantovani A, Sozzani S, Locati M, Allavena P, Sica A. Macrophage polarization: tumor-associated macrophages as a paradigm for polarized M2 mononuclear phagocytes. Trends Immunol (2002) 23(11):549-55. doi:10.1016/ S1471-4906(02)02302-5

156. Burdin N, Brossay L, Kronenberg M. Immunization with alpha-galactosylceramide polarizes CD1-reactive NK $\mathrm{T}$ cells towards Th2 cytokine synthesis. Eur J Immunol (1999) 29(6):2014-25. doi:10.1002/ (SICI)1521-4141(199906)29:06<2014::AID-IMMU2014>3.0.CO;2-G

157. Gottschalk C, Mettke E, Kurts C. The role of invariant natural killer T cells in dendritic cell licensing, cross-priming, and memory CD8(+) T cell generation. Front Immunol (2015) 6:379. doi:10.3389/fimmu.2015.00379

158. Terabe M, Matsui S, Park JM, Mamura M, Noben-Trauth N, Donaldson DD, et al. Transforming growth factor-beta production and myeloid cells are an effector mechanism through which CD1d-restricted $\mathrm{T}$ cells block cytotoxic $\mathrm{T}$ lymphocyte-mediated tumor immunosurveillance: abrogation prevents tumor recurrence. J Exp Med (2003) 198(11):1741-52. doi:10.1084/jem. 20022227

159. Park JM, Terabe M, van den Broeke LT, Donaldson DD, Berzofsky JA. Unmasking immunosurveillance against a syngeneic colon cancer by elimination of CD4+ NKT regulatory cells and IL-13. Int J Cancer (2005) 114(1):80-7. doi:10.1002/ijc.20669

160. O'Garra A. Cytokines induce the development of functionally heterogeneous T helper cell subsets. Immunity (1998) 8(3):275-83. doi:10.1016/ S1074-7613(00)80533-6

161. Levings MK, Sangregorio R, Galbiati F, Squadrone S, de Waal Malefyt R, Roncarolo MG. IFN-alpha and IL-10 induce the differentiation of human type $1 \mathrm{~T}$ regulatory cells. J Immunol (2001) 166(9):5530-9. doi:10.4049/ jimmunol.166.9.5530

162. Galli G, Nuti S, Tavarini S, Galli-Stampino L, De Lalla C, Casorati G, et al. CD1d-restricted help to B cells by human invariant natural killer T lymphocytes. J Exp Med (2003) 197(8):1051-7. doi:10.1084/jem.20021616

163. Tonti E, Fedeli M, Napolitano A, Iannacone M, von Andrian UH, Guidotti LG, et al. Follicular helper NKT cells induce limited B cell responses and germinal center formation in the absence of CD4(+) T cell help. JImmunol (2012) 188(7):3217-22. doi:10.4049/jimmunol.1103501

164. Barral P, Eckl-Dorna J, Harwood NE, De Santo C, Salio M, Illarionov P, et al. B cell receptor-mediated uptake of CD1d-restricted antigen augments antibody responses by recruiting invariant NKT cell help in vivo. Proc Natl Acad Sci U S A (2008) 105(24):8345-50. doi:10.1073/pnas.0802968105

165. Leadbetter EA, Brigl M, Illarionov P, Cohen N, Luteran MC, Pillai S, et al. NK T cells provide lipid antigen-specific cognate help for B cells. Proc Natl Acad Sci U S A (2008) 105(24):8339-44. doi:10.1073/pnas. 0801375105 
166. Chang YJ, Huang JR, Tsai YC, Hung JT, Wu D, Fujio M, et al. Potent immune-modulating and anticancer effects of NKT cell stimulatory glycolipids. Proc Natl Acad Sci U S A (2007) 104(25):10299-304. doi:10.1073/ pnas.0703824104

167. Brigl M, Brenner MB. CD1: antigen presentation and T cell function. Annu Rev Immunol (2004) 22:817-90. doi:10.1146/annurev.immunol.22.012703. 104608

168. Nieuwenhuis EE, Matsumoto T, Exley M, Schleipman RA, Glickman J, Bailey DT, et al. CD1d-dependent macrophage-mediated clearance of Pseudomonas aeruginosa from lung. Nat Med (2002) 8(6):588-93. doi:10.1038/nm0602-588

169. Sada-Ovalle I, Chiba A, Gonzales A, Brenner MB, Behar SM. Innate invariant NKT cells recognize Mycobacterium tuberculosis-infected macrophages, produce interferon-gamma, and kill intracellular bacteria. PLoS Pathog (2008) 4(12):e1000239. doi:10.1371/journal.ppat.1000239

170. Hegde S, Chen X, Keaton JM, Reddington F, Besra GS, Gumperz JE. NKT cells direct monocytes into a DC differentiation pathway. J Leukoc Biol (2007) 81(5):1224-35. doi:10.1189/jlb.1206718

171. Xu H, Kramer M, Spengler HP, Peters JH. Dendritic cells differentiated from human monocytes through a combination of IL-4, GM-CSF and IFN-gamma exhibit phenotype and function of blood dendritic cells. Adv Exp Med Biol (1995) 378:75-8. doi:10.1007/978-1-4615-1971-3_15

172. Kobayashi E, Motoki K, Uchida T, Fukushima H, Koezuka Y. KRN7000, a novel immunomodulator, and its antitumor activities. Oncol Res (1995) 7(10-11):529-34.

173. Morita M, Motoki K, Akimoto K, Natori T, Sakai T, Sawa E, et al. Structureactivity relationship of alpha-galactosylceramides against B16-bearing mice. J Med Chem (1995) 38(12):2176-87. doi:10.1021/jm00012a018

174. Motoki K, Morita M, Kobayashi E, Uchida T, Akimoto K, Fukushima H, et al. Immunostimulatory and antitumor activities of monoglycosylceramides having various sugar moieties. Biol Pharm Bull (1995) 18(11):1487-91. doi:10.1248/bpb.18.1487

175. Kawano T, Cui J, Koezuka Y, Toura I, Kaneko Y, Motoki K, et al. CD1drestricted and TCR-mediated activation of valpha14 NKT cells by glycosylceramides. Science (1997) 278(5343):1626-9. doi:10.1126/science.278. 5343.1626

176. Nakui M, Ohta A, Sekimoto M, Sato M, Iwakabe K, Yahata T, et al. Potentiation of antitumor effect of NKT cell ligand, alpha-galactosylceramide by combination with IL-12 on lung metastasis of malignant melanoma cells. Clin Exp Metastasis (2000) 18(2):147-53. doi:10.1023/A:1006715221088

177. Smyth MJ, Crowe NY, Pellicci DG, Kyparissoudis K, Kelly JM, Takeda K, et al. Sequential production of interferon-gamma by NK1.1(+) $\mathrm{T}$ cells and natural killer cells is essential for the antimetastatic effect of alphagalactosylceramide. Blood (2002) 99(4):1259-66. doi:10.1182/blood.V99. 4.1259

178. Toura I, Kawano T, Akutsu Y, Nakayama T, Ochiai T, Taniguchi M. Cutting edge: inhibition of experimental tumor metastasis by dendritic cells pulsed with alpha-galactosylceramide. J Immunol (1999) 163(5):2387-91.

179. Hayakawa Y, Rovero S, Forni G, Smyth MJ. Alpha-galactosylceramide (KRN7000) suppression of chemical- and oncogene-dependent carcinogenesis. Proc Natl Acad Sci U S A (2003) 100(16):9464-9. doi:10.1073/ pnas. 1630663100

180. Smyth MJ, Thia KY, Street SE, Cretney E, Trapani JA, Taniguchi M, et al. Differential tumor surveillance by natural killer (NK) and NKT cells. J Exp Med (2000) 191(4):661-8. doi:10.1084/jem.191.4.661

181. Nishikawa H, Kato T, Tawara I, Takemitsu T, Saito K, Wang L, et al. Accelerated chemically induced tumor development mediated by CD4+CD25+ regulatory T cells in wild-type hosts. Proc Natl Acad Sci U S A (2005) 102(26):9253-7. doi:10.1073/pnas.0503852102

182. Swann JB, Uldrich AP, van Dommelen S, Sharkey J, Murray WK, Godfrey DI, et al. Type I natural killer T cells suppress tumors caused by p53 loss in mice. Blood (2009) 113(25):6382-5. doi:10.1182/blood-2009-01-198564

183. Gebremeskel S, Clattenburg DR, Slauenwhite D, Lobert L, Johnston B. Natural killer T cell activation overcomes immunosuppression to enhance clearance of postsurgical breast cancer metastasis in mice. Oncoimmunology (2015) 4(3):e995562. doi:10.1080/2162402X.2014.995562

184. Gebremeskel S, Lobert L, Tanner K, Walker B, Oliphant T, Clarke LE, et al. Natural killer T-cell immunotherapy in combination with chemotherapyinduced immunogenic cell death targets metastatic breast cancer. Cancer Immunol Res (2017) 5(12):1086-97. doi:10.1158/2326-6066.CIR-17-0229
185. Smyth MJ, Cretney E, Takeda K, Wiltrout RH, Sedger LM, Kayagaki N, et al. Tumor necrosis factor-related apoptosis-inducing ligand (TRAIL) contributes to interferon gamma-dependent natural killer cell protection from tumor metastasis. J Exp Med (2001) 193(6):661-70. doi:10.1084/ jem.193.6.661

186. Hayakawa Y, Takeda K, Yagita H, Kakuta S, Iwakura Y, Van Kaer L, et al. Critical contribution of IFN-gamma and NK cells, but not perforin-mediated cytotoxicity, to anti-metastatic effect of alpha-galactosylceramide. Eur J Immunol (2001) 31(6):1720-7. doi:10.1002/1521-4141(200106)31:6<1720::AIDIMMU1720>3.0.CO;2-U

187. O'Konek JJ, Illarionov P, Khursigara DS, Ambrosino E, Izhak L, Castillo BF II, et al. Mouse and human iNKT cell agonist beta-mannosylceramide reveals a distinct mechanism of tumor immunity. J Clin Invest (2011) 121(2): 683-94. doi:10.1172/JCI42314

188. Schmieg J, Yang G, Franck RW, Tsuji M. Superior protection against malaria and melanoma metastases by a C-glycoside analogue of the natural killer T cell ligand alpha-galactosylceramide. J Exp Med (2003) 198(11):1631-41. doi:10.1084/jem.20031192

189. Aspeslagh S, Li Y, Yu ED, Pauwels N, Trappeniers M, Girardi E, et al. Galactose-modified iNKT cell agonists stabilized by an induced fit of CD1d prevent tumour metastasis. EMBO J (2011) 30(11):2294-305. doi:10.1038/ emboj.2011.145

190. Dashtsoodol N, Shigeura T, Tashiro T, Aihara M, Chikanishi T, Okada H, et al. Natural killer T cell-targeted immunotherapy mediating long-term memory responses and strong antitumor activity. Front Immunol (2017) 8:1206. doi:10.3389/fimmu.2017.01206

191. Metelitsa LS, Weinberg KI, Emanuel PD, Seeger RC. Expression of CD1d by myelomonocytic leukemias provides a target for cytotoxic NKT cells. Leukemia (2003) 17(6):1068-77. doi:10.1038/sj.leu.2402943

192. Takahashi T, Haraguchi K, Chiba S, Yasukawa M, Shibata Y, Hirai H. Valpha24+ natural killer $\mathrm{T}$-cell responses against $\mathrm{T}$-acute lymphoblastic leukaemia cells: implications for immunotherapy. Br J Haematol (2003) 122(2):231-9. doi:10.1046/j.1365-2141.2003.04429.x

193. Dhodapkar MV, Geller MD, Chang DH, Shimizu K, Fujii S, Dhodapkar KM, et al. A reversible defect in natural killer $\mathrm{T}$ cell function characterizes the progression of premalignant to malignant multiple myeloma. J Exp Med (2003) 197(12):1667-76. doi:10.1084/jem.20021650

194. Chong TW, Goh FY, Sim MY, Huang HH, Thike AA, Lim WK, et al. CD1d expression in renal cell carcinoma is associated with higher relapse rates, poorer cancer-specific and overall survival. J Clin Pathol (2015) 68(3):200-5. doi:10.1136/jclinpath-2014-202735

195. Ni C, Wu P, Wu X, Zhang T, Zhang T, Wang Z, et al. Thymosin alpha1 enhanced cytotoxicity of iNKT cells against colon cancer via upregulating CD1d expression. Cancer Lett (2015) 356(2 Pt B):579-88. doi:10.1016/j. canlet.2014.10.002

196. Gumperz JE, Roy C, Makowska A, Lum D, Sugita M, Podrebarac T, et al. Murine CD1d-restricted T cell recognition of cellular lipids. Immunity (2000) 12(2):211-21. doi:10.1016/S1074-7613(00)80174-0

197. Song L, Asgharzadeh S, Salo J, Engell K, Wu HW, Sposto R, et al. Valpha24invariant NKT cells mediate antitumor activity via killing of tumorassociated macrophages. J Clin Invest (2009) 119(6):1524-36. doi:10.1172/ JCI37869

198. Wu DY, Segal NH, Sidobre S, Kronenberg M, Chapman PB. Crosspresentation of disialoganglioside GD3 to natural killer T cells. J Exp Med (2003) 198(1):173-81. doi:10.1084/jem.20030446

199. Olshefski R, Ladisch S. Intercellular transfer of shed tumor cell gangliosides. FEBS Lett (1996) 386(1):11-4. doi:10.1016/0014-5793(96)00392-4

200. Nicol A, Nieda M, Koezuka Y, Porcelli S, Suzuki K, Tadokoro K, et al. Human invariant valpha24+ natural killer $\mathrm{T}$ cells activated by alpha-galactosylceramide (KRN7000) have cytotoxic anti-tumour activity through mechanisms distinct from T cells and natural killer cells. Immunology (2000) 99(2):229-34 doi:10.1046/j.1365-2567.2000.00952.x

201. Gansuvd B, Hagihara M, Yu Y, Inoue H, Ueda Y, Tsuchiya T, et al. Human umbilical cord blood NK T cells kill tumors by multiple cytotoxic mechanisms. Hum Immunol (2002) 63(3):164-75. doi:10.1016/S0198-8859(01) 00382-2

202. Nishimura T, Kitamura H, Iwakabe K, Yahata T, Ohta A, Sato M, et al. The interface between innate and acquired immunity: glycolipid antigen presentation by CD1d-expressing dendritic cells to NKT cells induces the 
differentiation of antigen-specific cytotoxic T lymphocytes. Int Immunol (2000) 12(7):987-94. doi:10.1093/intimm/12.7.987

203. Ishihara S, Nieda M, Kitayama J, Osada T, Yabe T, Kikuchi A, et al. Alphaglycosylceramides enhance the antitumor cytotoxicity of hepatic lymphocytes obtained from cancer patients by activating CD3-CD56+ NK cells in vitro. J Immunol (2000) 165(3):1659-64. doi:10.4049/jimmunol.165.3.1659

204. Escriba-Garcia L, Alvarez-Fernandez C, Tellez-Gabriel M, Sierra J, Briones J. Dendritic cells combined with tumor cells and alpha-galactosylceramide induce a potent, therapeutic and NK-cell dependent antitumor immunity in B cell lymphoma. J Transl Med (2017) 15(1):115. doi:10.1186/s12967017-1219-3

205. Ambrosino E, Terabe M, Halder RC, Peng J, Takaku S, Miyake S, et al. Cross-regulation between type I and type II NKT cells in regulating tumor immunity: a new immunoregulatory axis. J Immunol (2007) 179(8):5126-36. doi:10.4049/jimmunol.179.8.5126

206. Fichtner-Feigl S, Terabe M, Kitani A, Young CA, Fuss I, Geissler EK, et al. Restoration of tumor immunosurveillance via targeting of interleukin-13 receptor-alpha 2. Cancer Res (2008) 68(9):3467-75. doi:10.1158/0008-5472. CAN-07-5301

207. Zhao J, Bagchi S, Wang CR. Type II natural killer T cells foster the antitumor activity of CpG-oligodeoxynucleotides. Oncoimmunology (2014) 3:e28977. doi:10.4161/onci.28977

208. Bricard G, Cesson V, Devevre E, Bouzourene H, Barbey C, Rufer N, et al. Enrichment of human CD4+ V(alpha)24/Vbeta11 invariant NKT cells in intrahepatic malignant tumors. JImmunol (2009) 182(8):5140-51. doi:10.4049/jimmunol.0711086

209. Tachibana T, Onodera H, Tsuruyama T, Mori A, Nagayama S, Hiai H, et al. Increased intratumor Valpha24-positive natural killer $\mathrm{T}$ cells: a prognostic factor for primary colorectal carcinomas. Clin Cancer Res (2005) 11(20): 7322-7. doi:10.1158/1078-0432.CCR-05-0877

210. Hishiki T, Mise N, Harada K, Ihara F, Takami M, Saito T, et al. Invariant natural killer T infiltration in neuroblastoma with favorable outcome. Pediatr Surg Int (2018) 34(2):195-201. doi:10.1007/s00383-017-4189-x

211. Lundgren S, Warfvinge CF, Elebro J, Heby M, Nodin B, Krzyzanowska A, et al. The prognostic impact of NK/NKT cell density in periampullary adenocarcinoma differs by morphological type and adjuvant treatment. PLoS One (2016) 11(6):e0156497. doi:10.1371/journal.pone.0156497

212. Metelitsa LS, Wu HW, Wang H, Yang Y, Warsi Z, Asgharzadeh S, et al. Natural killer T cells infiltrate neuroblastomas expressing the chemokine CCL2. J Exp Med (2004) 199(9):1213-21. doi:10.1084/jem.20031462

213. Molling JW, Kolgen W, van der Vliet HJ, Boomsma MF, Kruizenga H, Smorenburg CH, etal. Peripheral bloodIFN-gamma-secreting Valpha24+Vbeta11+ NKT cell numbers are decreased in cancer patients independent of tumor type or tumor load. Int J Cancer (2005) 116(1):87-93. doi:10.1002/ijc.20998

214. Schneiders FL, de Bruin RC, van den Eertwegh AJ, Scheper RJ, Leemans CR, Brakenhoff $\mathrm{RH}$, et al. Circulating invariant natural killer T-cell numbers predict outcome in head and neck squamous cell carcinoma: updated analysis with 10-year follow-up. J Clin Oncol (2012) 30(5):567-70. doi:10.1200/ JCO.2011.38.8819

215. Molling JW, Langius JA, Langendijk JA, Leemans CR, Bontkes HJ, van der Vliet HJ, et al. Low levels of circulating invariant natural killer $\mathrm{T}$ cells predict poor clinical outcome in patients with head and neck squamous cell carcinoma. JClin Oncol (2007) 25(7):862-8. doi:10.1200/JCO.2006. 08.5787

216. Crough T, Purdie DM, Okai M, Maksoud A, Nieda M, Nicol AJ. Modulation of human Valpha24(+)Vbeta11(+) NKT cells by age, malignancy and conventional anticancer therapies. Br JCancer (2004) 91(11):1880-6. doi:10.1038/sj.bjc.6602218

217. Giaccone G, Punt CJ, Ando Y, Ruijter R, Nishi N, Peters M, et al. A phase I study of the natural killer T-cell ligand alpha-galactosylceramide (KRN7000) in patients with solid tumors. Clin Cancer Res (2002) 8(12):3702-9.

218. Singh AK, Shukla NK, Das SN. Altered invariant natural killer T cell subsets and its functions in patients with oral squamous cell carcinoma. Scand J Immunol (2013) 78(5):468-77. doi:10.1111/sji.12104

219. Tahir SM, Cheng O, Shaulov A, Koezuka Y, Bubley GJ, Wilson SB, et al. Loss of IFN-gamma production by invariant NK T cells in advanced cancer. J Immunol (2001) 167(7):4046-50. doi:10.4049/jimmunol.167.7.4046

220. Klatka J, Grywalska E, Hymos A, Krasowska E, Mielnik M, Siwicka-Gieroba D, et al. Subpopulations of natural killer-T-like cells before and after surgical treatment of laryngeal cancer. Cent Eur JImmunol (2017) 42(3):252-8. doi:10.5114/ceji.2017.70967

221. Klatka J, Grywalska E, Wasiak M, Markowicz J, Trojanowski P, Olszanski W, et al. The percentage of iNKT cells among other immune cells at various clinical stages of laryngeal cancer. Postepy Hig Med Dosw (Online) (2016) 70:392-9. doi:10.5604/17322693.1200688

222. Yanagisawa K, Seino K, Ishikawa Y, Nozue M, Todoroki T, Fukao K. Impaired proliferative response of $\mathrm{V}$ alpha 24 NKT cells from cancer patients against alpha-galactosylceramide. J Immunol (2002) 168(12):6494-9. doi:10.4049/ jimmunol.168.12.6494

223. Motohashi S, Okamoto Y, Yoshino I, Nakayama T. Anti-tumor immune responses induced by iNKT cell-based immunotherapy for lung cancer and head and neck cancer. Clin Immunol (2011) 140(2):167-76. doi:10.1016/j. clim.2011.01.009

224. Exley MA, Lynch L, Varghese B, Nowak M, Alatrakchi N, Balk SP. Developing understanding of the roles of CD1d-restricted $\mathrm{T}$ cell subsets in cancer reversing tumor-induced defects. Clin Immunol (2011) 140(2):184-95. doi:10.1016/j.clim.2011.04.017

225. Xie D, Zhu S, Bai L. Lactic acid in tumor microenvironments causes dysfunction of NKT cells by interfering with mTOR signaling. Sci China Life Sci (2016) 59(12):1290-6. doi:10.1007/s11427-016-0348-7

226. Wang H, Yang D, Xu W, Wang Y, Ruan Z, Zhao T, et al. Tumor-derived soluble MICs impair CD3(+)CD56(+) NKT-like cell cytotoxicity in cancer patients. Immunol Lett (2008) 120(1-2):65-71. doi:10.1016/j.imlet.2008.07.001

227. RenukaradhyaGJ,SriramV,DuW,Gervay-HagueJ,VanKaerL,BrutkiewiczRR. Inhibition of antitumor immunity by invariant natural killer $\mathrm{T}$ cells in a T-cell lymphoma model in vivo. Int J Cancer (2006) 118(12):3045-53. doi:10.1002/ ijc. 21764

228. Quatromoni JG, Eruslanov E. Tumor-associated macrophages: function, phenotype, and link to prognosis in human lung cancer. Am J Transl Res (2012) 4(4):376-89.

229. Metelitsa LS. Anti-tumor potential of type-I NKT cells against CD1d-positive and CD1d-negative tumors in humans. Clin Immunol (2011) 140(2):119-29. doi:10.1016/j.clim.2010.10.005

230. Hayakawa Y, Takeda K, Yagita H, Smyth MJ, Van Kaer L, Okumura K, et al. IFN-gamma-mediated inhibition of tumor angiogenesis by natural killer T-cell ligand, alpha-galactosylceramide. Blood (2002) 100(5):1728-33.

231. Sun T, Yang Y, Luo X, Cheng Y, Zhang M, Wang K, et al. Inhibition of tumor angiogenesis by interferon-gamma by suppression of tumor-associated macrophage differentiation. Oncol Res (2014) 21(5):227-35. doi:10.3727/0 96504014X13890370410285

232. Courtney AN, Tian GW, Liu DF, Marinova E, Heczey A, Xu X, et al. Crosstalk between NKT cells and tumor associated macrophages in the tumor microenvironment. J Immunol (2016) 196(1 Suppl):142.7.

233. Raker VK, Domogalla MP, Steinbrink K. Tolerogenic dendritic cells for regulatory T cell induction in man. Front Immunol (2015) 6:569. doi:10.3389/ fimmu.2015.00569

234. Taniguchi M, Harada M, Dashtsoodol N, Kojo S. Discovery of NKT cells and development of NKT cell-targeted anti-tumor immunotherapy. Proc Jpn Acad Ser B Phys Biol Sci (2015) 91(7):292-304. doi:10.2183/pjab.91.292

235. Lippitz BE. Cytokine patterns in patients with cancer: a systematic review. Lancet Oncol (2013) 14(6):e218-28. doi:10.1016/S1470-2045(12)70582-X

236. Whiteside TL. The role of regulatory $\mathrm{T}$ cells in cancer immunology. Immunotargets Ther (2015) 4:159-71. doi:10.2147/ITT.S55415

237. Zhang Z, Su T, He L, Wang H, Ji G, Liu X, et al. Identification and functional analysis of ligands for natural killer cell activating receptors in colon carcinoma. Tohoku J Exp Med (2012) 226(1):59-68. doi:10.6120/tjem. 226.59

238. de Kruijf EM, Sajet A, van Nes JG, Putter H, Smit VT, Eagle RA, et al. NKG2D ligand tumor expression and association with clinical outcome in early breast cancer patients: an observational study. BMC Cancer (2012) 12:24. doi:10.1186/1471-2407-12-24

239. Garrido F, Cabrera T, Concha A, Glew S, Ruiz-Cabello F, Stern PL. Natural history of HLA expression during tumour development. Immunol Today (1993) 14(10):491-9. doi:10.1016/0167-5699(93)90264-L

240. Garrido F, Ruiz-Cabello F, Cabrera T, Perez-Villar JJ, Lopez-Botet M, Duggan-Keen M, et al. Implications for immunosurveillance of altered HLA class I phenotypes in human tumours. Immunol Today (1997) 18(2):89-95. doi:10.1016/S0167-5699(96)10075-X 
241. Marincola FM, Jaffee EM, Hicklin DJ, Ferrone S. Escape of human solid tumors from T-cell recognition: molecular mechanisms and functional significance. Adv Immunol (2000) 74:181-273. doi:10.1016/S0065-2776(08)60911-6

242. Seliger B, Cabrera T, Garrido F, Ferrone S. HLA class I antigen abnormalities and immune escape by malignant cells. Semin Cancer Biol (2002) 12(1):3-13. doi:10.1006/scbi.2001.0404

243. Chen ML, Pittet MJ, Gorelik L, Flavell RA, Weissleder R, von Boehmer H, et al. Regulatory $\mathrm{T}$ cells suppress tumor-specific CD8 T cell cytotoxicity through TGF-beta signals in vivo. Proc Natl Acad Sci U S A (2005) 102(2):419-24. doi:10.1073/pnas.0408197102

244. Strauss L, Bergmann C, Szczepanski M, Gooding W, Johnson JT, Whiteside TL. A unique subset of CD4+CD25highFoxp3+ T cells secreting interleukin-10 and transforming growth factor-betal mediates suppression in the tumor microenvironment. Clin Cancer Res (2007) 13(15 Pt 1):4345-54. doi:10.1158/ 1078-0432.CCR-07-0472

245. Nair S, Dhodapkar MV. Natural killer T cells in cancer immunotherapy. Front Immunol (2017) 8:1178. doi:10.3389/fimmu.2017.01178

246. Ishikawa A, Motohashi S, Ishikawa E, Fuchida H, Higashino K, Otsuji M, et al. A phase I study of alpha-galactosylceramide (KRN7000)-pulsed dendritic cells in patients with advanced and recurrent non-small cell lung cancer. Clin Cancer Res (2005) 11(5):1910-7. doi:10.1158/1078-0432.CCR-04-1453

247. Chang DH, Osman K, Connolly J, Kukreja A, Krasovsky J, Pack M, et al. Sustained expansion of NKT cells and antigen-specific T cells after injection of alpha-galactosyl-ceramide loaded mature dendritic cells in cancer patients. J Exp Med (2005) 201(9):1503-17. doi:10.1084/jem.20042592

248. Uchida T, Horiguchi S, Tanaka Y, Yamamoto H, Kunii N, Motohashi S, et al. Phase I study of alpha-galactosylceramide-pulsed antigen presenting cells administration to the nasal submucosa in unresectable or recurrent head and neck cancer. Cancer Immunol Immunother (2008) 57(3):337-45. doi:10.1007/ s00262-007-0373-5

249. Nicol AJ, Tazbirkova A, Nieda M. Comparison of clinical and immunological effects of intravenous and intradermal administration of alpha-galactosylceramide (KRN7000)-pulsed dendritic cells. Clin Cancer Res (2011) 17(15):5140-51. doi:10.1158/1078-0432.CCR-10-3105

250. Nieda M, Okai M, Tazbirkova A, Lin H, Yamaura A, Ide K, et al. Therapeutic activation of Valpha24+Vbeta11+ NKT cells in human subjects results in highly coordinated secondary activation of acquired and innate immunity. Blood (2004) 103(2):383-9. doi:10.1182/blood-2003-04-1155

251. Motohashi S, Nagato K, Kunii N, Yamamoto H, Yamasaki K, Okita K, et al. A phase I-II study of alpha-galactosylceramide-pulsed IL-2/GM-CSF-cultured peripheral blood mononuclear cells in patients with advanced and recurrent non-small cell lung cancer. J Immunol (2009) 182(4):2492-501. doi:10.4049/ jimmunol.0800126

252. Nagato K, Motohashi S, Ishibashi F, Okita K, Yamasaki K, Moriya Y, et al. Accumulation of activated invariant natural killer $\mathrm{T}$ cells in the tumor microenvironment after alpha-galactosylceramide-pulsed antigen presenting cells. J Clin Immunol (2012) 32(5):1071-81. doi:10.1007/s10875-012-9697-9

253. Motohashi S, Ishikawa A, Ishikawa E, Otsuji M, Iizasa T, Hanaoka H, et al. A phase I study of in vitro expanded natural killer $\mathrm{T}$ cells in patients with advanced and recurrent non-small cell lung cancer. Clin Cancer Res (2006) 12(20 Pt 1):6079-86. doi:10.1158/1078-0432.CCR-06-0114

254. Exley MA, Friedlander P, Alatrakchi N, Vriend L, Yue S, Sasada T, et al. Adoptive transfer of invariant NKT cells as immunotherapy for advanced melanoma: a phase I clinical trial. Clin Cancer Res (2017) 23(14):3510-9. doi:10.1158/1078-0432.CCR-16-0600

255. Yamasaki K, Horiguchi S, Kurosaki M, Kunii N, Nagato K, Hanaoka H, et al. Induction of NKT cell-specific immune responses in cancer tissues after NKT cell-targeted adoptive immunotherapy. Clin Immunol (2011) 138(3):255-65. doi:10.1016/j.clim.2010.11.014

256. Kunii N, Horiguchi S, Motohashi S, Yamamoto H, Ueno N, Yamamoto S, et al. Combination therapy of in vitro-expanded natural killer $\mathrm{T}$ cells and alpha-galactosylceramide-pulsed antigen-presenting cells in patients with recurrent head and neck carcinoma. Cancer Sci (2009) 100(6):1092-8. doi:10.1111/j.1349-7006.2009.01135.x
257. Bollino D, Webb TJ. Chimeric antigen receptor-engineered natural killer and natural killer T cells for cancer immunotherapy. Transl Res (2017) 187:32-43. doi:10.1016/j.trsl.2017.06.003

258. Stirnemann K, Romero JF, Baldi L, Robert B, Cesson V, Besra GS, et al. Sustained activation and tumor targeting of NKT cells using a CD1d-antiHER2-scFv fusion protein induce antitumor effects in mice. JClin Invest (2008) 118(3):994-1005. doi:10.1172/JCI33249

259. Corgnac S, Perret R, Derre L, Zhang L, Stirnemann K, Zauderer M, et al. CD1d-antibody fusion proteins target iNKT cells to the tumor and trigger long-term therapeutic responses. Cancer Immunol Immunother (2013) 62(4):747-60. doi:10.1007/s00262-012-1381-7

260. Horn LA, Ciavattone NG, Atkinson R, Woldergerima N, Wolf J, Clements VK, et al. CD3xPDL1 bi-specific T cell engager (BiTE) simultaneously activates $\mathrm{T}$ cells and NKT cells, kills PDL1(+) tumor cells, and extends the survival of tumor-bearing humanized mice. Oncotarget (2017) 8(35):57964-80. doi:10.18632/oncotarget. 19865

261. Gasser O, Sharples KJ, Barrow C, Williams GM, Bauer E, Wood CE, et al. A phase I vaccination study with dendritic cells loaded with NY-ESO-1 and alpha-galactosylceramide: induction of polyfunctional $\mathrm{T}$ cells in high-risk melanoma patients. Cancer Immunol Immunother (2018) 67(2):285-98. doi:10.1007/s00262-017-2085-9

262. Watarai H, Yamada D, Fujii S, Taniguchi M, Koseki H. Induced pluripotency as a potential path towards iNKT cell-mediated cancer immunotherapy. Int J Hematol (2012) 95(6):624-31. doi:10.1007/s12185-012-1091-0

263. Watarai H, Fujii S, Yamada D, Rybouchkin A, Sakata S, Nagata Y, et al. Murine induced pluripotent stem cells can be derived from and differentiate into natural killer T cells. J Clin Invest (2010) 120(7):2610-8. doi:10.1172/ JCI42027

264. Yamada D, Iyoda T, Vizcardo R, Shimizu K, Sato Y, Endo TA, et al. Efficient regeneration of human Valpha24(+) invariant natural killer T cells and their anti-tumor activity in vivo. Stem Cells (2016) 34(12):2852-60. doi:10.1002/ stem. 2465

265. Parekh VV, Lalani S, Kim S, Halder R, Azuma M, Yagita H, et al. PD-1/PD-L blockade prevents anergy induction and enhances the anti-tumor activities of glycolipid-activated invariant NKT cells. J Immunol (2009) 182(5):2816-26. doi:10.4049/jimmunol.0803648

266. Kamata T, Suzuki A, Mise N, Ihara F, Takami M, Makita Y, et al. Blockade of programmed death-1/programmed death ligand pathway enhances the antitumor immunity of human invariant natural killer T cells. Cancer Immunol Immunother (2016) 65(12):1477-89. doi:10.1007/s00262-016-1901-y

267. Klatka J, Grywalska E, Hymos A, Guz M, Polberg K, Rolinski J, et al. Cyclooxygenase-2 inhibition enhances proliferation of NKT cells derived from patients with laryngeal cancer. Anticancer Res (2017) 37(8):4059-66. doi:10.21873/anticanres.11791

268. Laurent X, Bertin B, Renault N, Farce A, Speca S, Milhomme O, et al. Switching invariant natural killer $\mathrm{T}$ (iNKT) cell response from anticancerous to anti-inflammatory effect: molecular bases. J Med Chem (2014) 57(13):5489-508. doi:10.1021/jm4010863

269. Liu Z, Guo J. NKT-cell glycolipid agonist as adjuvant in synthetic vaccine. Carbohydr Res (2017) 452:78-90. doi:10.1016/j.carres.2017.10.006

270. Carreno LJ, Saavedra-Avila NA, Porcelli SA. Synthetic glycolipid activators of natural killer T cells as immunotherapeutic agents. Clin Transl Immunology (2016) 5(4):e69. doi:10.1038/cti.2016.14

Conflict of Interest Statement: The authors declare that the research was conducted in the absence of any commercial or financial relationships that could be construed as a potential conflict of interest.

Copyright $\odot 2018$ Krijgsman, Hokland and Kuppen. This is an open-access article distributed under the terms of the Creative Commons Attribution License (CC BY). The use, distribution or reproduction in other forums is permitted, provided the original author(s) and the copyright owner are credited and that the original publication in this journal is cited, in accordance with accepted academic practice. No use, distribution or reproduction is permitted which does not comply with these terms. 